\title{
Influence of energy mix on the life cycle of an eco-neighborhood, a case study of 150 countries
}

\author{
Modeste Kameni Nematchoua a, b, *, Somayeh Asadi ${ }^{c}$, Sigrid Reiter ${ }^{b}$ \\ ${ }^{a}$ Beneficiary of an AXA Research Fund Postdoctoral Grant, Research Leaders Fellowships, AXA SA 25 avenue Matignon, 75008, Paris, France \\ ${ }^{\mathrm{b}}$ LEMA, ArGEnCo Department, University of Liège, Belgium \\ ${ }^{\mathrm{c}}$ Department of Architectural Engineering, Pennsylvania State University, USA
}

\section{A R T I C L E I N F O}

Article history:

Received 15 December 2019

Received in revised form 2 July 2020

Accepted 28 July 2020

Available online 12 August 2020

\section{Keywords:}

Life cycle

Energy mix

Eco-neighborhood

Biodiversity

\begin{abstract}
A B S T R A C T
In recent years, the destruction of the ecosystem, due to the strong emission of greenhouse gas into the atmosphere by humans has led to significant damage to wildlife, human health, and flora. This has significantly changed the human life cycle. Nowadays, the environmental damage costs are applied for the countries strongly impacting pollutant emission. To this end, developing countries receive annual compensation from the countries considered to be the most polluting. So far, decision-makers seem to be unaware that, at the scale of an eco-neighborhood, some emerging countries produce also a significant amount of $\mathrm{CO}_{2}$. The main purpose of this research is to quantify and to compare the effect of the energy mix of 150 countries on three environmental impacts generated by an eco-neighborhood: greenhouse effect, energy demand, and biodiversity damage. To perform this comparison, the same neighborhood design is applied to 150 countries, but four parameters are adapted to each country: energy mix, local climate, building materials, and occupants' mobility. In addition, this research evaluates the induced environmental costs of the neighborhood over a life cycle of 100 years and examines the impact of mobility and photovoltaic panel on these environmental costs. The different environmental impacts were evaluated by the Pleiades ACV simulation software under four phases (construction, use, renovation, and demolition), before being translated into environmental costs. Among the four local parameters (energy mix, local materials, climate, and transport), the energy mix has the most significant effect on the three studied environmental impacts. The results show that the countries having a higher concentration of renewable energy sources produce lower $\mathrm{CO}_{2}$ than others. Domestic and material wastes are also one of the main sources of greenhouse gas emissions and biodiversity damage in a sustainable neighborhood. The biodiversity damage is high in Sub-Sahara Africa, and MiddleEast, but low in the USA, Brazil, European Union, Russia, and Australia. The implementation of photovoltaic panels in a sustainable neighborhood mitigates, on average, $15.9 \%$ of carbon dioxide emissions and $21.2 \%$ of primary energy demand; but, unfortunately, this solution increases up to $25.0 \%$ the biodiversity damage.
\end{abstract}

() 2020 Elsevier Ltd. All rights reserved.

\section{Introduction}

The greenhouse effect is considered a natural phenomenon causing a rise in the temperature on the surface of our planet. Human activities affect the chemical composition of the atmosphere and lead to the emergence of an additional greenhouse effect, largely responsible for the current climate change [1]. According to the Intergovernmental Panel on Climate Change

\footnotetext{
* Corresponding author. LEMA, ArGEnCo Department, University of Liège, Belgium.

E-mail address: kameni.modeste@yahoo.fr (M.K. Nematchoua).
}

(IPCC), two-third of the energy from the sun is absorbed by the atmosphere, the soil, and the ocean. The remaining third is directly reflected back to space by clouds, aerosols, the atmosphere, and the earth's surface [2]. Human activities have a direct implication on energy demand and the degradation of biodiversity. Energy consumption in the building sector is an important part of global energy consumption [3]. In fact, buildings consume almost $40 \%$ of all energy and contribute to almost $30 \%$ of annual global greenhouse gas emissions [4]. Observing, the massive growth of new constructions in economies in transition, some researchers have shown that if nothing is done, greenhouse gas emissions from buildings will be more than double over the next few decades [5]. The energy 
consumed during the life cycle of a building can be divided into operational energy, intrinsic energy, and decommissioning energy [6]. Each phase of the life cycle of a building affects the environment and must be studied to produce a high-performance, energyefficient building [6]. The urban mobility of occupants has an important influence on on $\mathrm{CO}_{2}$ emission and energy demand in the neighborhoods. Encouraging the displacement of the population with public transports, such as bus and train, could help to reduce significantly these emissions [7]. Designing energy-efficient buildings are first and foremost about reducing energy requirements to a minimum, without compromising comfort. To do this, the implementation of passive strategies can be a solution $[8,9]$.

Environmental risk assessment is central to maintaining the life cycle of humankind. The decline of biodiversity is a global concern that needs to be addressed urgently. Globally, several scientists explained that the world's biodiversity is suffering from alarming damages. These ones are the result of growing human pressure on land use, agriculture, urbanization, tourism, forestry, etc. [10-12].

Since the 1970s, a general awareness has emerged of environmental problems. At the neighborhood scale, the Life Cycle Assessment (LCA) method is part of clearly validated scientific methods. LCA of buildings is even standardized at the European level. It is currently the only scientifically sound approach to carry out an environmental assessment at the neighborhood scale. It allows a quantitative study of the environmental impacts of constructions over the whole of their life cycle [13].

Buyle et al. [11] explained that impact assessment is the quantification of environmental effects, based on the inventory. Three steps are necessary: the selection of impact categories according to the purpose of the study, aggregation of the results of the impact category inventory, and the calculation of the indicators corresponding to each impact category. Colombert et al. [14] showed that the urban population is becoming aware of the need to preserve biodiversity and green spaces. Olivier-Solà et al. [15] found that it is highly likely that the environmental and energy issues we are currently dealing with at the building level will soon be transferred to the urban scale. Lotteau et al. [16] explained that the neighborhood life cycle analysis is complex, multifunctional, and changing and that its life is long. These previous studies raise many new issues regarding how to apply the LCA method at the neighborhood scale, especially regarding the definition of the functional unit or the consideration of temporal aspects. Moreover, no standard dictates the procedure to follow at this scale. In 2006, Popovici [17] proposed a definition of the neighborhood according to three elements: buildings, public spaces, and networks, considering a life cycle from cradle to the end of life. Stephan et al. [18] demonstrate that energy use during the operational phase is the primary contribution to environmental impacts over the entire life cycle of a neighborhood. Indeed, it accounts for almost $40 \%$ of primary energy consumption (PEC) and more than $42 \%$ of greenhouse gas emissions (GHG). By comparing several urban developments of different densities, Norman et al. [19] conclude that mobility contributes much more significantly to total energy consumption and GHG emissions in a low-density urban development than in the case of dense development. By comparing four scenarios, based on different types of residential buildings, Trigaux et al. [20] showed that the contribution of road infrastructures accounts for $1 \%-6 \%$ of total impacts.

The different environmental impacts generated important costs each year. Environmental cost assessment methodologies allow quantifying them. Some of these methods were updated on the basis of the methodologies developed previously by Debacker et al. [21] and DeNocker et al. [22]. Niemelä et al. [23] showed that the optimization of heat pump systems greatly reduces the environmental impact costs compared to the building envelope efficiency. The same result was found by Atmaca [24]. Moreover, several scientific papers have already proposed different methods of optimizing the Life Cycle Cost (LCC) to explore energy efficiency measures [25-28]. Tokarik and Richman [29] suggested that several optimization methods can be used to mitigate the LCC of a Toronto house up to $33 \%$.

However, the results of all these studies strongly depended on climate. A lot of studies in the literature have already been focusing on life-cycle analysis at the building scale and very little at the neighborhood scale, focusing mainly on the analysis of only one environmental parameter or life cycle cost. Other studies focus solely on optimizing environmental impacts with the implementation of photovoltaic panels. More recent studies are rather oriented on the optimization of heating pumps. In addition, maintenance, demolition of residences, and recycling of materials are often neglected in LCA studies on the built environment. It is important to note that all of these studies mainly focus on the issues of one country/region. These studies have great local interest. However, it is time to scale up these studies and focus on the world scale. Problems related to climate change, greenhouse gas emissions, biodiversity degradation, and energy demand should be solved on an international scale. Every country should feel concerned and be aware of the extreme environmental damage, the necessity, and the urgency to find solutions. In this study, we pushed thinking further. There are a total of 12 types of environmental impacts for an LCA. This study focuses only on three factors of LCA (Energy, Carbon, and Biodiversity) because they are the most significant and the most well-known of the twelve.

The main purpose of this research is to quantify and to compare the impact of climate, energy mix, local building materials, installation of PV panels, and mobility behaviors on three environmental impacts including greenhouse gas effect, energy demand, and biodiversity damage generated by an eco-neighborhood over its life cycle in 150 countries. Unlike previous studies that only focused on a single life cycle stage (e.g., renovation or use), all four phases including construction, use, renovation, and demolition were considered in this study.

\section{Research methodology}

We carried out the environmental analysis of a sustainable neighborhood located in Belgium (Europe) over 100 years, and then, we adopted the same design in 149 other countries, while keeping four parameters specific to each country: energy mix, local climate, building materials, and occupants' mobility. In addition, we calculated the costs related to three environmental impacts: greenhouse effect, energy demand, and biodiversity degradation. Finally, we varied different design parameters to quantify their effects on the environmental costs of the neighborhood. Overall, this methodology is divided into five main sections (a) neighborhood selection and site modeling; (b) LCA of the selected neighborhood; (c) modeling the same neighborhood in 149 other countries with adaptation of the four local parameters and life cycle assessment; (d) calculation of the cost of the three studied environmental impacts; (e) applying one scenario for mitigating some environmental costs.

The following sections $(2.1-2.6)$ will describe some methodological choices: the case study, the chosen countries and databases, the environmental database and the environmental indicators studied, the LCA simulation software used, the environmental cost calculation method, the improvement scenario tested. 


\subsection{Initial analysis of the eco-neighborhood}

This neighborhood is initially located in the Liege city in Belgium, and the same design is adapted in 149 countries represented in the world. The Sart-Tilman eco-neighborhood in Liege is one of the privileged places of Belgium, where the concepts of a sustainable neighborhood have been applied. This econeighborhood offers different types of buildings (terraced and semi-detached houses, apartment buildings, etc.). A majority of the built surface is dedicated to housing, but we also find spaces dedicated to commercial functions or the liberal professions and small businesses. In total, we counted 40 small apartments, 45 larger homes, 11 single-family duplex homes, and 6 complementary functions (businesses and shops). Private parking spaces are planned near the buildings. All the dwellings located on the ground floor have a private garden. An aerial view of the studied neighborhood is showed in Fig. 1.

In this neighborhood, the buildings were designed with respect to the passive standard, which imposes very low energy consumption. Moreover, this new neighborhood meets almost all the criteria of a sustainable neighborhood, following the references published by the University of Liege and other international Organizations $[30,31]$. The site is strongly served by public transport linking it to the center of Liege, thanks to the proximity of the university. The neighborhood has a built density of 40 dwellings per hectare. Outdoor spaces are landscaped with more than $30 \%$ "green" or "blue" surfaces and separate water management for rainwater and wastewater. Rainwater recovery systems and tanks are also implemented.

In this research, only the neighborhood residential part was studied. The calculated environmental impacts correspond to the residential eco-district of 3.5 ha comprising 1 ha of roads, driveways and parking lots, $17800 \mathrm{~m}^{2}$ of green space, $19740 \mathrm{~m}^{2}$ of floor space, housing around 219 inhabitants, studied on a life cycle of 100 years. Given the construction standards in Belgium compared to those of other countries, it is clear that Belgian buildings would hardly exist in Asian cities, the Middle East, Africa, and South America. For this, firstly, we have made a sensitivity study. Thus, in this study, we take into account country-specific standards for the choice of local materials. In the literature, it is seen that the density of living space per person is very specific to each country, the inhabitants of Asian countries occupying very little space, and the inhabitants of North America and Australia occupying very large spaces per person. To remedy this problem, in this study, in the case of developed countries in Europe, North America, some Asian countries and

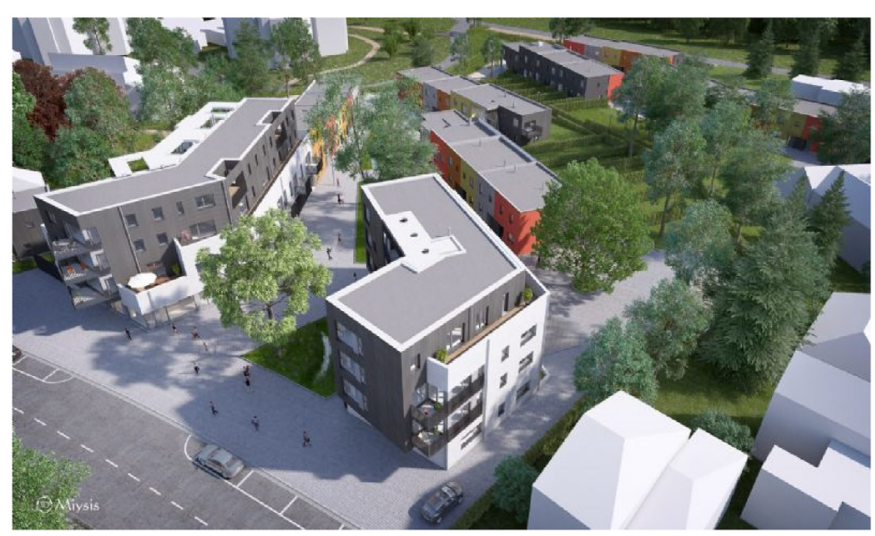

Fig. 1. The studied eco-neighborhood, near the University of Liege, in Belgium (See these videos: www.youtube.com/watch?v=FDzdAaMy_3Ywww.youtube.com/watch? time_continue $=81 \&$ amp; $=$ hdX2abFvebo).
Australia, we maintained 219 occupants in all the neighborhood, while in the case of others Asian country, Middle East, Africa, South America, we have fixed 438 (219x2) occupants (this technique allowed us to reduce the space occupied per person in these countries).

\subsection{Design of the same eco-neighborhood in other countries}

The same eco-neighborhood is built in 150 capitals located in 150 countries. The choice of the capital, for representing each country was not random; indeed, in most of these countries, the capital was considered as the most populated region of the country, with the highest pollution rate and energy consumption. This strong population concentration has a significant influence on all the environmental impacts.

We simultaneously applied four parameters for adapting this neighborhood in each country: the energy mix of each country, the local climate of each country, typical building materials used in each country, and occupants' mobility. Only the four parameters that influence building performance were selected because several studies have shown that these different parameters have a more significant impact on the different environmental impacts. In addition, it is practically impossible to consider all the parameters existing at the neighborhood level. An example of a case in five countries located in five continents is showed in Table 1.

The International Energy Agency (IEA) database [32] and the Energy Information System of each country were used to gather the information on the energy mix and electricity mix. On the PleaidesACV software, it was possible to freely select the different energy components mix (in \%) or electricity mix (in \%), such as nuclear, fuel, coal, gas, and renewable energy; then, assigning their corresponding values.

The information on the local climate of each country was evaluated with the most recent Meteonorm software version. Meteonorm is defined as a meteorological database with climatological data for every location on the globe [33]. The fixed database in Meteonorm 7.3.1 contains approximately 6200 cities, 8325 weather stations, and 1200 Design Reference Year sites.

The information on the construction materials was evaluated on the basis of 2018-2020 standard thermal regulation of each country, but also from information issue to the UN-habitat [65], and some literature reviews (for some African and Asian countries, without recent building standards). Regarding inhabitant mobility, the data was freely selected on Pleaides software [66]. These data are based on a different rate of occupants commuting daily: $80 \%$ in developed countries (USA, Japan, Germany, France, UK, etc.) and $50 \%$ in developing countries (Cameroon, Madagascar, Haiti, Thailand, etc.). The distance of the weekly commute between home and trade is $1000 \mathrm{~m}$; distance from the public transport network is $500 \mathrm{~m}$, distance from the daily commute to work is on average between $5000 \mathrm{~m}$ and $10000 \mathrm{~m}$. Presence of bike path: yes; public transportation: bus, subway, and tram [66].

\subsection{Environmental database and studied indicators}

The environmental data used come from the ECOINVENT database developed by different research institutes based in Switzerland. These data include, for each process and material, a life cycle inventory that contains all material and energy flow into and out of the system [34]: (i) resources consumed (water, energy, etc.); (ii) emissions in the different natural environments: air, water or soils (ammonia in water, metals in the soil, $\mathrm{CO}_{2}$, etc.); (iii) waste created (inert, toxic or radioactive). We used version 2.2 (2012) of the ECOINVENT database. This version was completed by the latest version, ECOINVENT 3.5 (2018). The development of this database 
Table 1

Example of input parameters taken in five countries.

\begin{tabular}{|c|c|c|c|c|c|c|}
\hline Continents & Europe & Africa & America & Asia & Oceania & Source \\
\hline Countries & Belgium & Madagascar & United States & China & Australia & \\
\hline Capitals & Brussels & Antananarivo & Washington & Beijing & Canberra & \\
\hline \multirow[t]{5}{*}{ Energy mix (2016) } & -Nuclear: 52\% & -Coal: $20.7 \%$ & -Nuclear 9\% & -Nuclear: $10 \%$ & -Coal 6.8\% & \multirow[t]{5}{*}{ [32] } \\
\hline & -Hydraulic: 17\% & -Oil: $65.5 \%$ & -Renewable energy:11\% & $\begin{array}{l}\text {-Renewable } \\
\text { energy: } 1.7 \%\end{array}$ & -Gas $22 \%$ & \\
\hline & -Coal:4\% & - Hydraulic: $13.8 \%$ & -Coal:14\% & -Coal:63.7\% & -Oil: $36 \%$ & \\
\hline & -Oil:0\% & & -Oil: $37 \%$ & -Oil: 19\% & -Hydraulic:20\% & \\
\hline & -Gas: $27 \%$ & & -Gas:29\% & -Gas:5.6\% & -Nuclear: $15.2 \%$ & \\
\hline $\begin{array}{l}\text { Local climate (According to Köppen } \\
\text { climate classification) }\end{array}$ & $\begin{array}{l}\text { Temperate oceanic } \\
\text { climate }(\mathrm{Cfb})\end{array}$ & $\begin{array}{l}\text { Tropical wet and dry } \\
\text { climate (AW/AS) }\end{array}$ & $\begin{array}{l}\text {-Oceanic climate (Cfb) } \\
\text {-Mediterranean warm/cool- } \\
\text { summer climates (Csb) } \\
\text { - Humid continental } \\
\text { climate(Dfb) }\end{array}$ & $\begin{array}{l}\text { Humid continental } \\
\text { climate (Dwa) }\end{array}$ & $\begin{array}{l}\text { Temperate oceanic } \\
\text { climate }(\mathrm{Cfb})\end{array}$ & [33] \\
\hline
\end{tabular}

follows processes that have been verified several times to make sure they are reliable and the contents of this database have been verified and validated by international experts. The ECOINVENT Centre is recognized as an international leader in environmental sustainability data and it is well known for the transparency of its methods [35].

In this study, we assessed three (03) environmental impacts of the studied neighborhood: the greenhouse effect (via the Global Warming Potential, GWP); Cumulative Energy Demand, and Biodiversity damage [36-38]. These different environmental indicators are presented in Table 2.

\subsection{LCA simulation software}

In this study, we used a combination of all the new IZUBA energy software. Indeed, the interface of the most recent version (Pleiades software, version 4.19.1.0)is divided into 6 modules: Library, Modeler(called ALCYONE for the old software version), BIM, Editor(called COMFIE-PLEIADES), Results, and ACV (nova-EQUER). It is important to notice that each one has a precise function. All of them are regularly used by numerous international research laboratories and have been clearly validated by the scientific community $[14,39,40]$.

Modeler, ALCYONE software, is a graphical input tool. It allows the description of the geometry of a building, to represent its solar masks and to define the composition of the walls. Also using this software we defined the zoning of the building where the thermal behavior is homogeneous [14]. This software is essentially made up of five components: Generals (Construction Data, Project Library, LCA Association, Weather and Horizon); Plan; 3D; Calculation. Some physical characteristics of the studied neighborhood are shown in Tables 3 and 4.

Editor, COMFIE-PLEIADES software, allows the performance of dynamic thermal simulation for buildings [14,39]. The geometry created via "Modeler" can be imported from the information entered concerning the materials, the occupation scenarios, and the meteorological data, the software evaluates the heating and air conditioning needs. It is possible to disaggregate the results based on the thermal zone or by a period of time. This neighborhood was regrouped in 10 blocks with heating requirements shown in Table 5.

ACV module,nova-EQUER, is the environmental quality assessment tool. The requirements calculated in "Editor" are exported and additional inputs are provided to complete the LCA. It includes data such as the energy mix, the mobility of users, the constitution of outdoor spaces, and networks. The software then performs the LCA of the buildings and neighborhood and presents results in the form of radars compiling the different impacts with the possibility of visualizing the part of each phase of the life cycle and comparing different variants of the same project [39]. This module is essentially made up of:

\subsubsection{Building/neighborhood data}

The original data come from the Pleiades, this thermal/ACV coupling allows to automatically recover all the characteristics of the building: data on the structure of the building and the elements involved in thermal calculations and/or energy consumption. These data are then supplemented with specific LCA data: all elements that are not part of the thermal study; general and administrative data concerning the current operation and the building or neighborhood; specific or adjusted seizures for energy, water, waste, and transport.

\subsection{2. (ii)Software organization}

The Pleiades interface is structured around five axes:

(a) Library: Environmental Impact Data Libraries, General Calculation Characteristics. In this research, we fixed: the surplus of materials at the site $5 \%$, default typical service life of families of element: interior and exterior doors 30 years, global equipment 20 years, glazing 30 years, coating 10 years; the distance of transport: site of production towards building site $100 \mathrm{~km}$, site towards inert discharge finally of life: $20 \mathrm{~km}$.

(b) Project: Project management with structure data for any type of project and use of the building with the EQUER engine. In this research, we fixed: Loss of electrical network

Table 2

Average LCA results of the eco-neighborhood (in Liege city) in terms of calculated impacts.

\begin{tabular}{|c|c|c|c|c|}
\hline \multirow[t]{2}{*}{ Environmental indicator } & \multirow[t]{2}{*}{ unity } & \multirow[t]{2}{*}{ Value over 100 years } & Value/inhabitant & \multirow[t]{2}{*}{ Value $/ \mathrm{m}^{2}$ per year } \\
\hline & & & Per year & \\
\hline Energy & GJ & 3232.62 & 1.115 & 0.035 \\
\hline Greenhouse effect & $\mathrm{t} \mathrm{CO}_{2} \mathrm{eq}$ & 92419.00 & 31.869 & 1.010 \\
\hline Biodiversity damage & $\mathrm{PDF}^{*} \mathrm{~m}^{2}$ & 154146.62 & 53.154 & 1.685 \\
\hline
\end{tabular}


Table 3

Wall composition.

\begin{tabular}{|c|c|c|c|c|c|}
\hline Element & component & $\mathrm{E}(\mathrm{cm})$ & $\rho^{*} \mathrm{e}\left(\mathrm{kg} / \mathrm{m}^{2}\right)$ & $\lambda(\mathrm{w} / \mathrm{m} . \mathrm{k})$ & $\mathrm{R}\left(\mathrm{m}^{2} . \mathrm{K} / \mathrm{W}\right)$ \\
\hline \multirow[t]{4}{*}{ Coated exterior wall } & exterior coating & 1.5 & 26.0 & 1.150 & 0.01 \\
\hline & Expanded polystyrene & 32.0 & 8.0 & 0.032 & 10.0 \\
\hline & Limestone silico block & 15.0 & 270.0 & 0.136 & 1.10 \\
\hline & ceiling & 1.3 & 11.0 & 0.325 & 0.04 \\
\hline \multirow{5}{*}{ Barded outer wall } & Cement fiber cladding & 2.0 & 36.0 & 0.950 & 0.02 \\
\hline & Air blade & 1.2 & 0.0 & 0.080 & 0.15 \\
\hline & polyurethane & 24.0 & 7.0 & 0.025 & 9.60 \\
\hline & Limestone silico block & 15.0 & 27.0 & 0.136 & 1.10 \\
\hline & ceiling & 1.3 & 11.0 & 0.325 & 0.04 \\
\hline \multirow[t]{4}{*}{ High floor } & PDM sealing & - & - & - & - \\
\hline & Polyurethane & 40.0 & 12 & 0.025 & 16.00 \\
\hline & Concrete slab & 25.0 & 325 & 1.389 & 0.18 \\
\hline & Ceiling & 1.3 & 11 & 0.325 & 0.04 \\
\hline \multirow[t]{5}{*}{ Intermediate floor } & Chappe + coating & 8.0 & 144 & 0.700 & 0.11 \\
\hline & polyurethane & 1.0 & 0 & 0.030 & 0.33 \\
\hline & Aerated concrete & 8.0 & 48 & 0.210 & 0.38 \\
\hline & Concrete slab & 25.0 & 325 & 1.389 & 0.18 \\
\hline & Ceiling & 1.3 & 11 & 0.325 & 0.04 \\
\hline \multirow[t]{3}{*}{ Low floor } & Chappe + coating & 8.0 & 144 & 0.700 & 0.11 \\
\hline & polyurethane & 25.0 & 8 & 0.025 & 10.00 \\
\hline & Concrete slab & 25.0 & 575 & 1.750 & 0.14 \\
\hline \multirow[t]{5}{*}{ Internal wall } & Ceiling & 1.3 & 11 & 0.325 & 0.04 \\
\hline & Limestone silico block & 15.0 & 270 & 0.136 & 1.1 \\
\hline & Expanded polystyrene & 4.0 & 1 & 0.032 & 1.25 \\
\hline & Limestone silico block & 15.0 & 270 & 0.136 & 1.10 \\
\hline & ceiling & 1.3 & 11 & 0.325 & 0.04 \\
\hline
\end{tabular}

(e) Thickness, $(\rho *$ e) the mass per unit area, $(\lambda)$ thermal conductivity and (R) thermal resistance.

Table 4

Wall surface states.

\begin{tabular}{lllll}
\hline & & Property & \\
\hline Location & coating & $\xi$ & $\mathrm{A}$ & $\mathrm{P}(\%)$ \\
External face & Red brick & 0.92 & 0.68 & 20 \\
Floor & concrete & 0.88 & 0.9 & 30 \\
External roof & gray gravel & 0.95 & 0.85 & 15 \\
Internal face & White paint & 0.91 & 0.2 & 80 \\
Ceiling & White paint & 0.91 & 0.2 & 80 \\
\hline
\end{tabular}

Emissivity $(\varepsilon)$, absorptivity $(\alpha)$, and reflectivity $(\rho)$ of the different coatings used.

Table 5

Heating requirements of different neighborhood buildings in the basic and high configuration of a floor.

\begin{tabular}{lll}
\hline \multirow{2}{*}{ Buildings } & \multicolumn{2}{l}{ Heating requirements $\left(\mathrm{kWh} / \mathrm{m}^{2}\right.$.year $)$} \\
\cline { 2 - 3 } & Initial situation & First floor \\
\hline A3 & 15 & 14 \\
B2 & 12 & 12 \\
B3 & 14 & 13 \\
D1 & 19 & 20 \\
D2 & 20 & 20 \\
D3 & 20 & 21 \\
D4 & 18 & 19 \\
C1 & 12 & 11 \\
C2 & 13 & 12 \\
C3 & 13 & 11 \\
Mean & 15.6 & 15.3 \\
\hline
\end{tabular}

Table 6

Monetary indicators for the European Committee for Standardization indicators [40].

\begin{tabular}{lll}
\hline Environmental Indicator & Unit & Value $€$ /unit \\
\hline Greenhouse gas & $\mathrm{kg} \mathrm{CO}_{2} \mathrm{eq}$ & 0.05 \\
Biodiversity damage & $\mathrm{PDF}^{2}$.year & $0.30-0.59$ \\
Energy demand & $\mathrm{kWh}$ & 0.2
\end{tabular}

CEN (European Committee for Standardization); ECC (European Consumer Centers); PDF (potentially disappeared fraction). from $9 \%$ to $40 \%$ according to country. Water system yield: $80 \%$, hot water consumption $40 \mathrm{~L} /$ day/person; cold water consumption 100L/day/person; Selective collection of glass: yes; sorted glass: $90 \%$; incinerated waste $40 \%$; recovery to incineration: yes; substituted energy: gas or fuel oil (depending on the country); recovery yield: $80 \%$; selective collection of paper: yes; sorted paper: $80 \%$; distance from the site to the garbage dump: $20 \mathrm{~km}$; distance from the site to the incinerator: $10 \mathrm{~km}$; distance from the site to the recycling center: $100 \mathrm{~km}$.

(c) Experimentation: Specific seizures PEBN E + C-; (at this stage, we introduced all the same experimental data as building structure, location, climate, etc.)

(d) Calculation and results: Start the calculations and consult the results(after having evaluated all the impacts from each of the constituents of the district (examples: buildings, road, garden transport, etc.), we combine all these elements to assess the impacts related to the district).

(e) Neighborhood: Neighborhood Management.

\subsection{Environmental cost calculation method}

The three environmental impacts will be translated into environmental costs, which make them comparable to each other. The cost calculation is based on the method Monetization of the MMG (Global method monetize) updated in 2017 [40], which is based on the methodologies developed previously by Debacker et al. [21] and De Nocker et al. [22]. Monetary values of each environmental indicator have been determined in this methodology [40] for three regions: Western Europe, Belgium, and the rest of the world. Note that the error margin related to the monetary value is low. The tables below show the conversion values of the environmental impacts of environmental costs.

Overall, the environmental cost is very important during the operation phase (71.1\%). The maintenance cost is estimated to be around $3.7 \%$ of the total environmental cost. These findings confirm the results found by Trigaux et al. [41]. 


\subsection{Mitigation of impacts}

In this study, we applied one scenario to study the mitigation potential of one sustainable strategy on the calculated environmental impacts and costs. This strategy consisted of applied photovoltaic panels combined with better inhabitants 'mobility behaviors.

In the initial scenario, all the electricity used came from the electricity grid of each country, and the production impacts were taken into account. In this new configuration, we will have a photovoltaic system on all the roofs on the site.Installed photovoltaic panels cover a total area of $580 \mathrm{~m}^{2}$ equivalent to a peak power of $82857.14 \mathrm{w}$. It must be noted that our homes use electricity only for light and to power household appliances. The installation will consist of monocrystalline photovoltaic solar panels. The sensors will be placed using support on the roof terrace. They will be oriented toward the south in the case of countries located in the northern hemisphere (Russia, Canada, China, United States, India, Kazakhstan, etc.), and toward the north in the case of countries located in the southern hemisphere (Angola, Botswana, Burundi, Comoros, Lesotho, Madagascar, Malawi, etc.); they will also be inclined at $37^{\circ}$ for the countries located in the temperate and cold zones and inclined at $45^{\circ}$ for the countries located in the hot zone. This allows us to have optimal inclination in all the countries. We have then performed the thermal simulation of each building and completed the final LCA of the neighborhood.

Let us now look at the impact of mobility on the neighborhood's environmental record. In our basic scenario, we considered a significant use of the car for daily commuting. We will compare this scenario with a second one, where the site is considered urban, perfectly integrated with public transport networks, and at a short distance from the shops of primary needs. Let us recapitulate the mobility hypotheses: (i) Initial scenario: $80 \%$ of the occupants commute daily in developed countries and $50 \%$ of the occupants commute daily in developing countries; the distance from home to work of 5-10 km is carried out daily by car; the distance from home to shops of $1 \mathrm{~km}$ is done weekly by car. (ii) new scenario or "Urban Site" scenario: $100 \%$ of the occupants make the trip daily in all the countries; the distance from home to work of $2-5 \mathrm{~km}$ is done daily by bus; the distance from home to shops of $0.5-1 \mathrm{~km}$ is carried out weekly by bike or on foot. Finally, both scenarios have been combined to obtain a mixed scenario having a significant effect on the three environmental impacts assessment.

This scenario was mainly applied to the case of 31 representative countries, selected among the 150 studied countries. These selected countries are located in the 5 continents (Fig. 9), covering the three climatic zones (Fig. 10), and covering the 7 different types of the climate of the world (Fig. 11). These countries were also selected under the base of their very significant energy mix and local building materials.

\section{Results and analysis}

This section analyzes the environmental impacts and costs of the reference scenario and a mitigation scenario. Then, the parameters that most influence the different environmental impacts are highlighted.

\subsection{Environmental impacts over 100years}

Figs. 2-4 show the results of the three environmental impacts assessment of studied neighborhood, adapted in 150 countries over a period of 100 years. Fig. 2 shows that the greenhouse effect is the most significant in some countries such as Australia, China, Poland, Madagascar, Mongolia, etc. This rate is low in countries such as
Denmark, Costa Rica, Finland, United Kingdom, Sweden, Switzerland, and Brazil. According to IEA [32], the percentage of renewable energy in the energy mix is of $43.0 \%$ in Denmark, $47.0 \%$ in Costa Rica, 29.6\% in Finland, and 33.3\% in Brazil (based on their energy mix in 2016). These percentages explain the low carbon concentration emissions in these countries compared to other countries. In addition, it is interesting to notice the carbon rate emission is moderate in the USA, Germany, Cameroon, and Argentina. These results show that countries such as the United States, Germany, and Russia emit average carbon content. This result is not a surprise, because, despite the rate of fossil energy use considered very high in these countries, it is offset by the implementation of sustainable or green energy sources. The heating of buildings is often supplied in these countries by nuclear energy and cooling by solar energy.

As shown in Fig. 3, primary energy demand is low (between 450000 GJ and 550000 GJ) in Brazil, Mali, Norway, and Singapore; the energy demand is moderate in USA, Namibia, Germany, and India, and very significant (more than $750000 \mathrm{GJ}$ over 100 years), in Australia, Canada, Kazakhstan, and South Africa.

The degradation of biodiversity is very high in Africa and the Middle East because of the non-renewal of waste. In these areas, there are several highly polluted sites. Industrial and petroleum wastes are often rejected on the African coast. On the contrary, it is seen that in most developed countries such as USA, the European Union, Russia, and Australia, biodiversity damage is the lowest (see Fig. 4).

Overall, among the four applied parameters (energy mix, local material, climate, and transport), the energy mix has the most significant effect on the three studied environmental impacts.

\subsection{Applied energy mix}

Fig. 5 shows the analysis of three environmental impacts per square meter living space per year coming from a neighborhood adapted in several regions in the world. As shown in Fig. 5a, the average of the greenhouse effect of an eco-neighborhood (including buildings, road construction, and daily mobility) located in the 150 studied countries is around $72.1 \mathrm{~kg} \mathrm{CO}_{2} / \mathrm{m}^{2}$.year and $60.31 \mathrm{~kg} \mathrm{CO} /$ $\mathrm{m}^{2}$.year in the 34 OECD countries. The greenhouse effect is higher than the average in countries such as Canada, China, India, and Australia, but also in southern Asia, Africa, and the Middle East. Contrary to certain results published by the IPCC, which stipulates that on a global scale, the developed countries emit an important quantity of greenhouse gases. It is also found in this research that at the scale of the sustainable neighborhood, greenhouse gas emissions are lower in the European Union than in Africa.

Fig. 5b shows that the average primary energy demand of an eco-neighborhood (including buildings, road construction, and daily mobility) is around $255.4 \mathrm{kWh} / \mathrm{m}^{2}$.year in the 150 countries. The energy demand is around to $319.1 \mathrm{kWh} / \mathrm{m}^{2}$.year in Canada, and $369.4 \mathrm{kWh} / \mathrm{m}^{2}$.year in Australia. This energy demand is $8.8 \%$ and $12.1 \%$, higher in the European Union, and Africa, respectively, than the average of other studied countries. However, it is found that this energy is $3.2 \%$ and $28.2 \%$ lower in the Middle East and Denmark, respectively, compared to the average in all the studied countries.

In Fig. 5c, it is interesting to notice that biodiversity damage is very low in Germany (1.8PDF. ${ }^{2}$.year) and the highest in Madagascar (13.62 PDF.m².year). These findings confirm the report of the United Nation which mentioned Madagascar as one of the countries in the world where fauna and fuel are in perpetual disappearance [42].

The effects of the energy mix on the environmental impacts in different countries are an innovative subject in recent research. They are evaluated nationally and consider different economic 


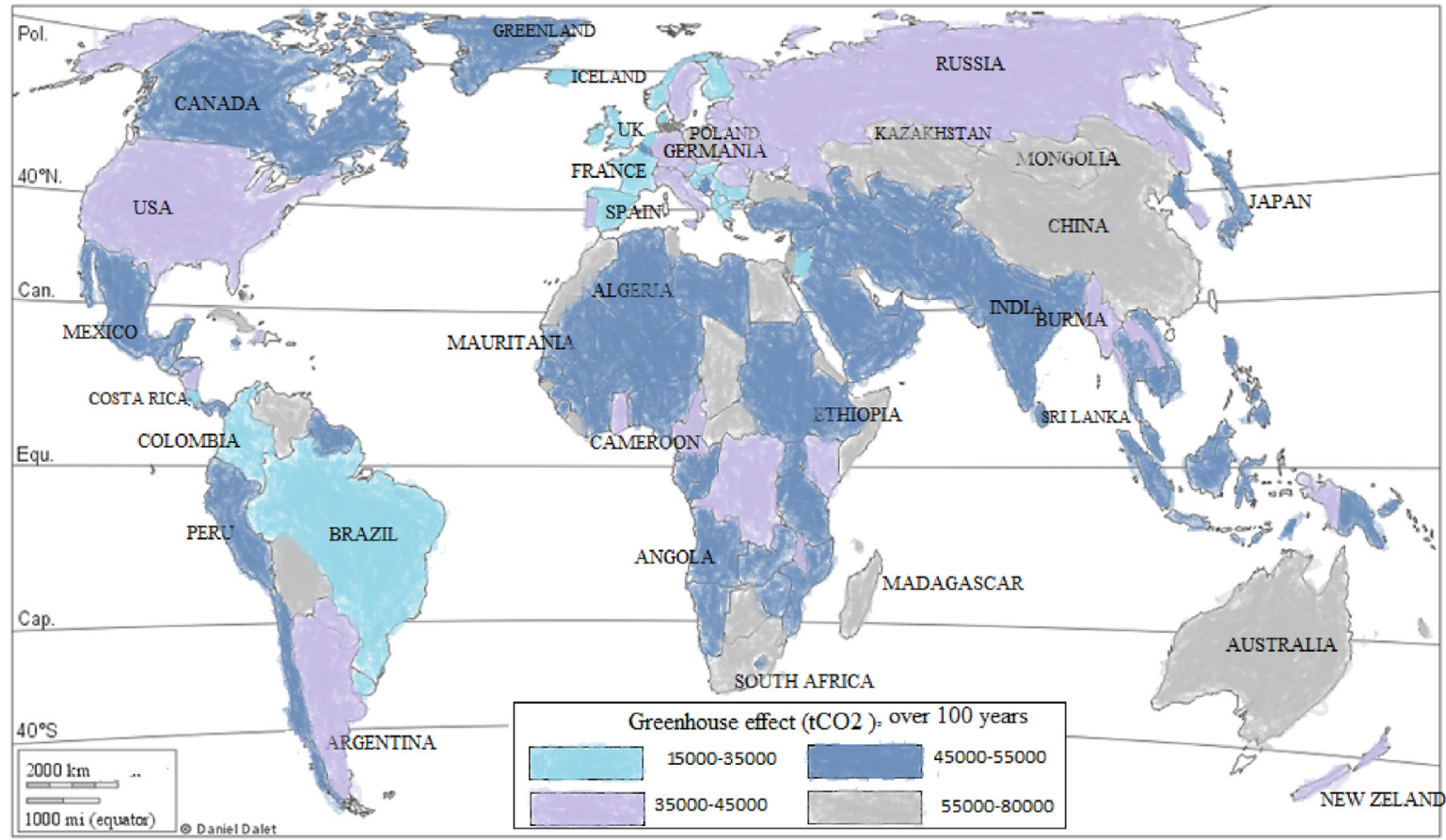

Fig. 2. Greenhouse effect assessment of a sustainable neighborhood, designed in 150 countries over a period of 100 years.

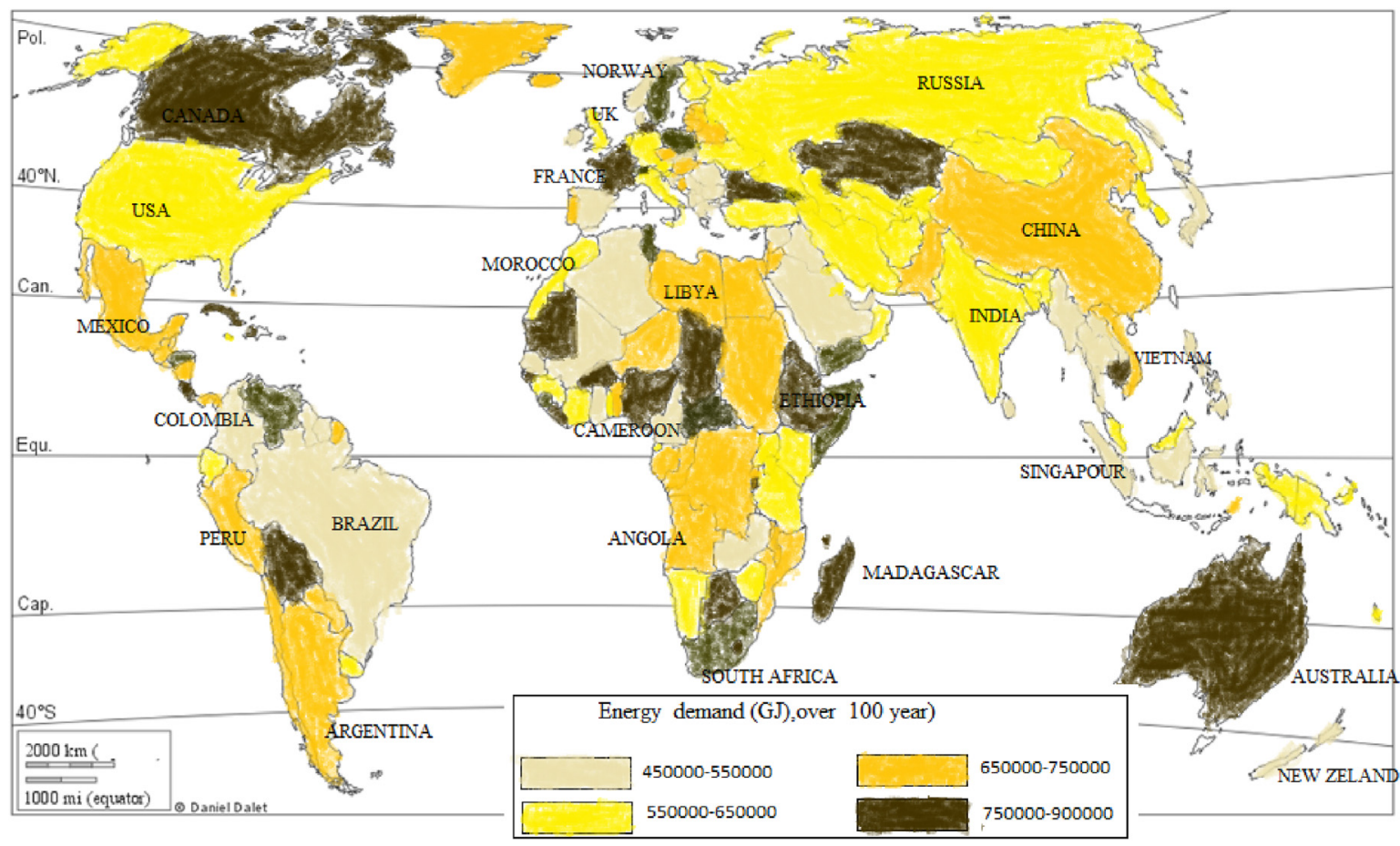

Fig. 3. Primary energy demand assessment of a sustainable neighborhood, designed in 150 countries over a period of 100 years.

problems of the countries, the variations of the energy supply, and the changes in the profile of demand [43-45]. Other studies on European countries explain how a sudden change in the energy mix towards fossil energy sources will lead to significant increases in emissions per occupant, nationally, and globally, even without increasing energy consumption [46-49].

Overall, compared to the mean of biodiversity damage (around 10.71PDF.m².year), the observed damage is $14.8 \%$ higher in Africa and 16.9\%higher in South Asia than the average value in the 150 countries. On the other side, biodiversity damage is $62.8 \%$ lower in the European Union than the average of all the studied countries. The average biodiversity damage is only 4.87 PDF. $\mathrm{m}^{2}$.year in the countries member of G7. 


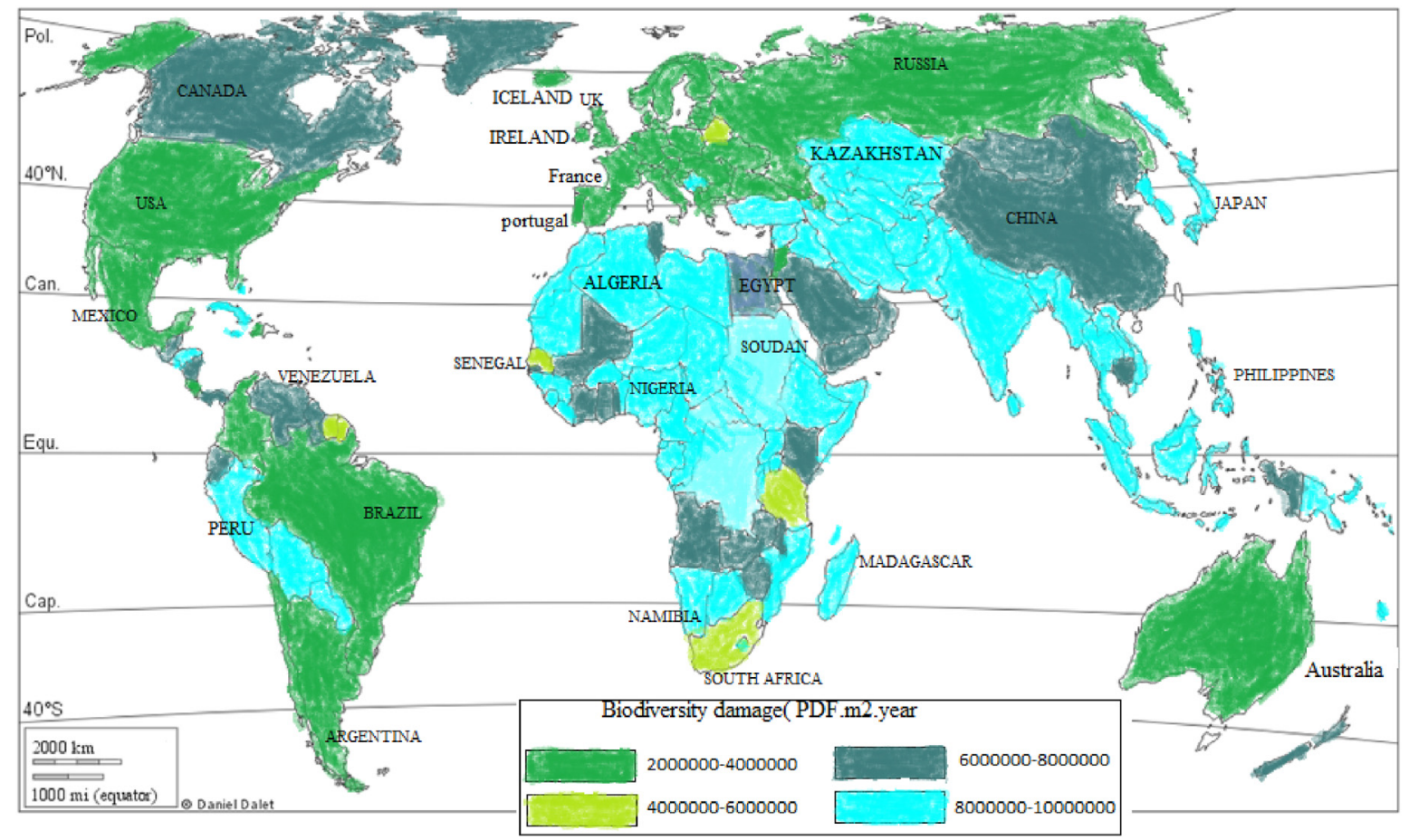

Fig. 4. Biodiversity damage evaluation of an eco-neighborhood, designed in 150 countries over a period of 100 years.

\subsection{Mitigating of environmental impacts}

To reduce environmental impacts, we have coupled two scenarios as detailed in section 2.6. The results are shown in Figs. 6-8.

Fig. 6 shows the significant effect of implementing the photovoltaic scenario on the carbon rate. Overall, the implementation of this method allows mitigating the greenhouse effect by up to $15.2 \%$. Indeed, the greenhouse effect is reduced by $9.5 \%$ in the hot zone, $18.2 \%$ in the temperate zone, and $15.9 \%$ in Africa. In addition, the carbon rate is mitigated up to $58.9 \%$ in Mexico, 25.4\%, in Australia, and $37.7 \%$ in Belgium. Despite this, it is seen that the implementation of the photovoltaic panel increases the greenhouse effect from $36.7 \%$ in Iran, $15.6 \%$ in Singapore, and 5.8\% in India. This may be due to the materials used in photovoltaic panels which are more suited to the temperate climate. These results show that the yield associated with the rate of carbon reduction is greater in the temperate zone than in the hot zone.

As shown in Fig. 7, primary energy demand is mitigated to $21.2 \%$ by adopting this new scenario. The saved energy is up to $18.9 \%$ in the temperate zone, $22.1 \%$ in the tropical climate regions, and $23.0 \%$ in Africa. In addition, this new method allows mitigating energy demand to $11.7 \%$ in Brazil, $4.4 \%$ in Russia, $29.7 \%$ in New Zeland, and $41.1 \%$ in Cameroon. These results showed that the implementation of the photovoltaic panel has the most significant effect (produce a high yield) in the countries with a tropical and arid climate, such as Singapore(26.8\% of saving energy), Qatar (41.3\%), etc. This result confirms those found by Laleman et al. [50] who explained that in regions with low solar radiation, the potential of photovoltaic electricity is not very high. However, this potential is 4 times higher compared to a wind farm. But, 10 times lower than that of electricity produced by a coal power plant. Overall, the PV-systems yield varied according to the countries. Jungbluth and Tuchschmid [51] estimated this yield around $725 \mathrm{kWh} / \mathrm{kWp} /$ year in some countries such as the UK and Belgium and $848 \mathrm{kWh} / \mathrm{kWp} / \mathrm{year}$ in Switzerland.

As shown on Fig. 8, overall, the biodiversity damage increases up to $24.9 \%$ in all regions by implementing the new scenario. This biodiversity damage increases to $23.8 \%$ in the European Union, 42.2\% in Africa, and $30.9 \%$ in some oceanic countries, such as New Zealand, Fiji, Papua New Guinea. It is interesting to see that biodiversity damage increases to $105 \%, 118 \%$, and $126 \%$, in the USA, Australia, and southern Africa, respectively. However, it decreases in some countries such as Brazil (0.07\%), Mexico (59.6\%), Canada (62.5\%), Argentina (22.9\%), Chile (53.6\%), etc. These results show that the significance of the biodiversity index varies according to the regions.

Global results show that installing photovoltaic panels in the eco-neighborhood mitigates carbon rate and primary energy demand. However, it increases the biodiversity damage in the temperate, hot, and polar climate zones. The energy yield of photovoltaic panels is the most significant in the countries having a tropical climate (see Table 6).

\subsection{Environmental costs}

Table 8 shows the values of the three environmental impacts and environmental costs calculated under the base of two scenarios coupled over one year of life, the case of 30 countries distributed in five continents, and covering different climate types.

According to the results shown in this table, the average spending cost per country regarding greenhouse gas emissions is estimated at $24509 € /$ year. The $15.5 \%$ of this cost can be saved, after implementing the photovoltaic and urban scenario. The average spending cost per country regarding biodiversity loss is estimated at $19108 € /$ year. This cost increases in mean to $14.7 \%$ by applying the new scenario(Photovoltaic + urban mobility). It is interesting to notice that:

(a) In UK (Europe), carbon cost decreases to $11.1 \%$ while biodiversity damage cost increases to $43.6 \%$; (b) in USA (America), carbon cost decreases to $7.0 \%$, while biodiversity damage cost increases to $105 \%$; (c) in China (Asia), carbon cost increases to $1.9 \%$, while biodiversity decreases to $33.2 \%$; (d) in Qatar (middle east), 


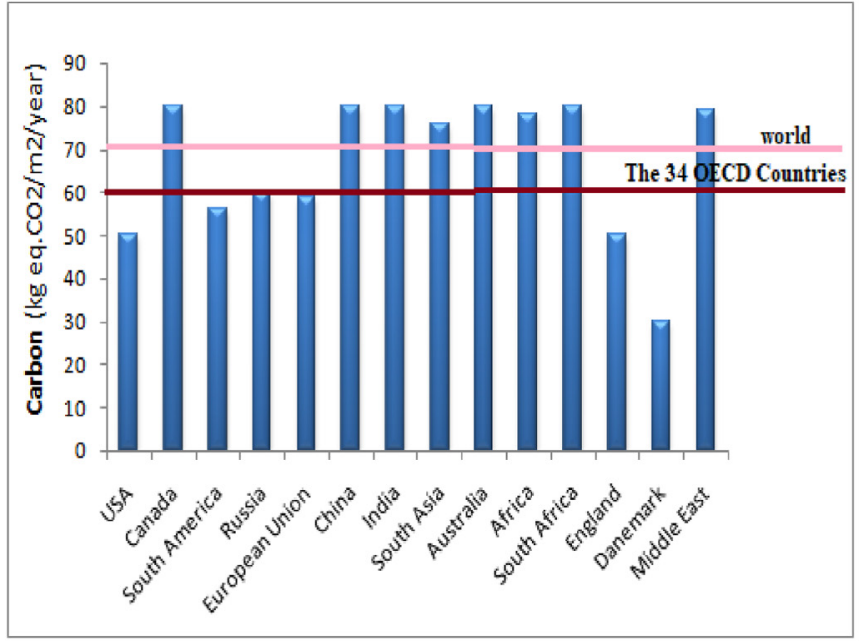

Figure 5a. Greenhouse effect for a sustainable neighborhood distributed in the world per square meter living space per year

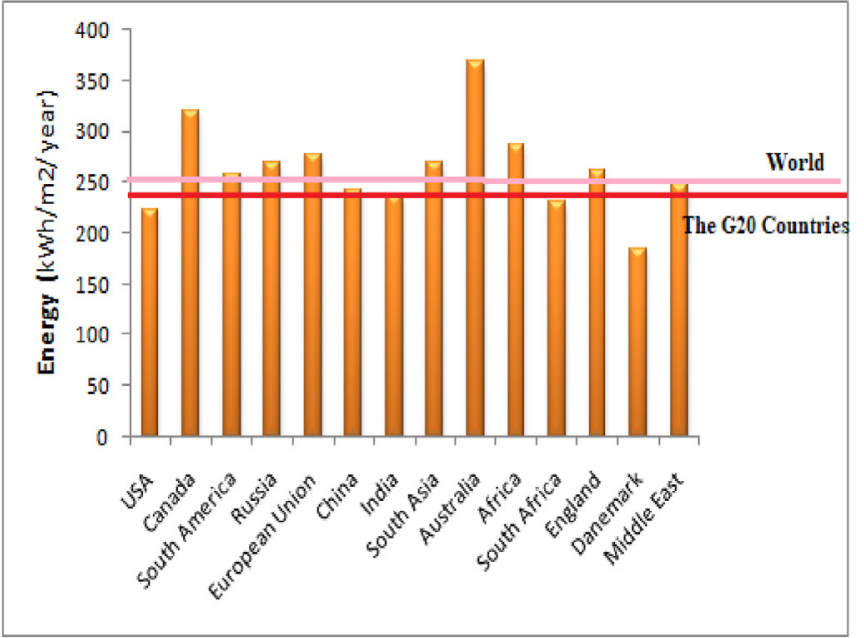

Figure 5b.Primary energy demand for a sustainable neighborhood distribued in the world per square meter living space per year

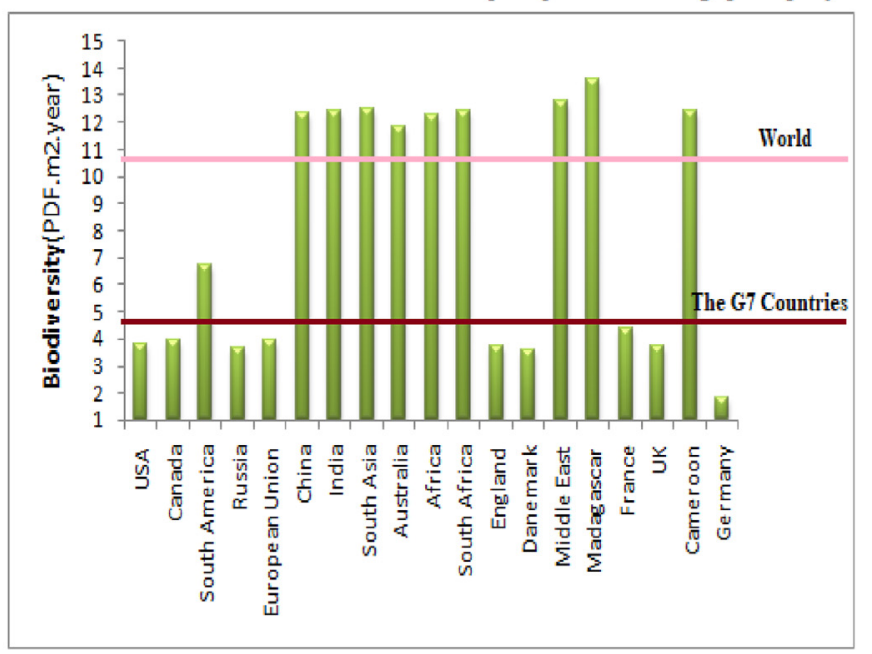

Figure $5 c$. Biodiversity damage for a sustainable neighborhood distributed in the world per square meter living space per year

Fig. 5. Assessment of three environmental impacts coming from a sustainable neighborhood distributed in some countries in the world.

carbon cost decreases to $18.6 \%$, while biodiversity damage cost increases to 131.3\%; (e) in Madagascar (Africa), carbon cost increases to $0.4 \%$, while biodiversity damage cost increases to $40.1 \%$; (f) and in Australia(Oceanic), carbon cost decreases to $25.4 \%$, while biodiversity damage cost increases to $118.5 \%$. These results may be compared to the conclusion of Zhou et al. [52] which showed that $\mathrm{CO}_{2}$ emissions vary in the same direction as energy, however, increasing more slowly than energy.

Table 9 gives the distribution of the three environmental impacts by region and their cost.

On Table 7, we see that the environmental cost and impact of the greenhouse effect are more important in central and northern Asia, and less important in Northern European. This can be explained by the fact that in most countries in North and Central Asia, the percentage of fossil fuel energy consumption (oil, coal, etc.) is above 80\%. While in Northern Europe, USA, and Australia, the proportion of fossil energy in the energy mix is very high, but some portion of it is slightly offset by green energy sources or renewable energy sources, which reduces the carbon content of an eco-neighborhood. In addition, biodiversity damage is low in the countries of the European union and very important in the countries of Africa union.

\subsection{Environmental components}

Fig. 9 shows the frequency of the different environmental components in the generation of the greenhouse gas effect, in 28 representative countries located in the five continents of the world (Europe, America, Africa, Asia, and Oceanic).

Overall, in an eco-neighborhood, the materials selected during the construction phase have a very low pollution rate. However, some materials can pollute enormously after a few years of use. For example, some types of insulations are manufactured under basic of petrol waste.

The greenhouse gas rate produced by waste or material degradation was 50.7\% in Germany, 29.9\% in Belgium, 38.5\% in France, and $33.8 \%$ in Iceland. At the neighborhood scale, electricity production is the main cause of greenhouse gas emissions in the USA(49.9\%), Spain (49.2\%), Argentina(47.5\%), Mexico(42.3\%), in Italy(41.7\%), Russia(38.8\%), and Canada(33.2\%). However, in Africa and Asia, electricity and waste are the two main environmental components of greenhouse gas emissions. Globally, it is found in this research that the main sources of greenhouse gas emissions in the different countries are: electricity production and waste. 


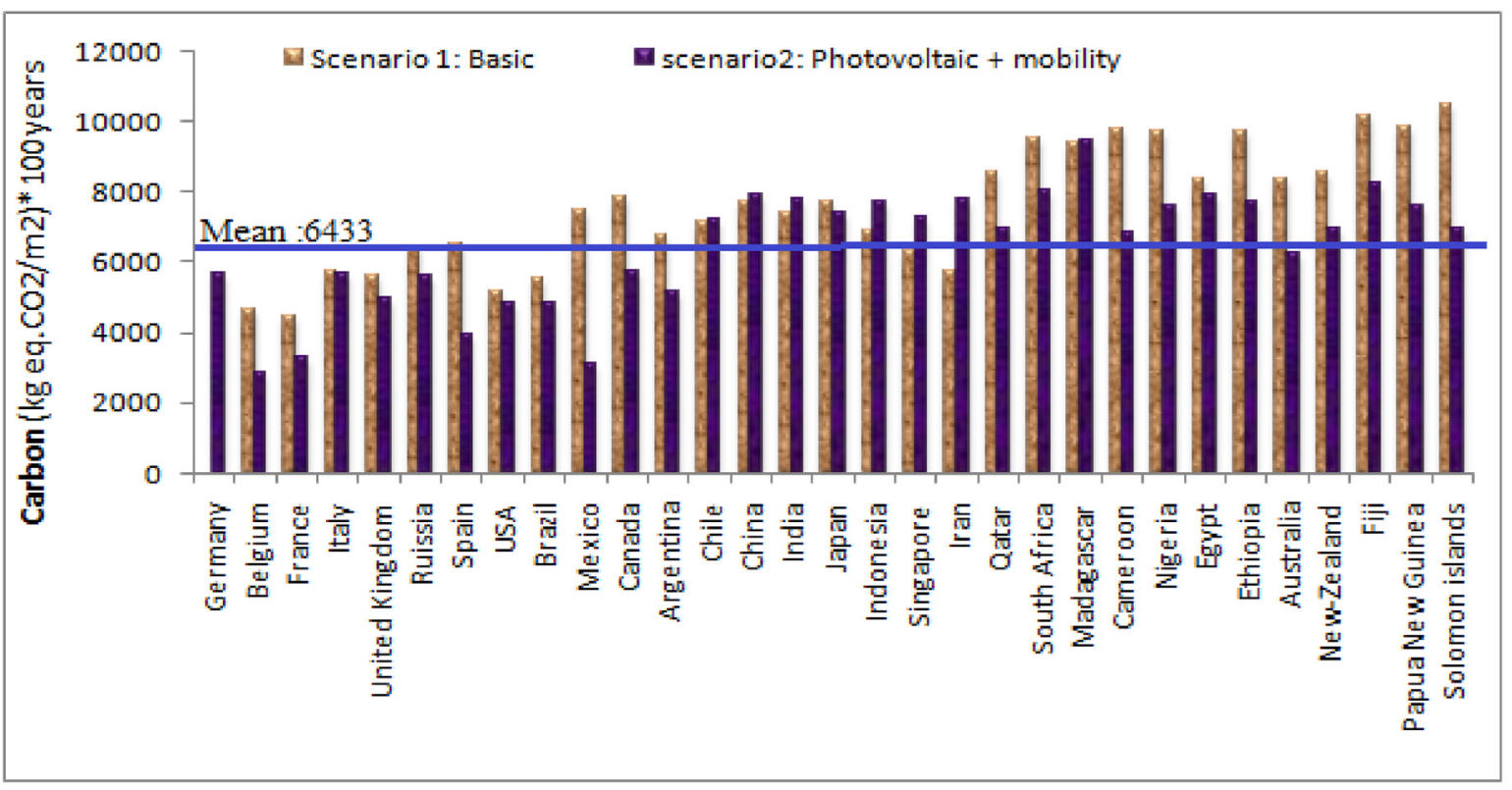

Fig. 6. Comparative diagram of the Carbon Impact of the "Initial" and "Photovoltaic" Scenarios (Functional Unit: Entire neighborhood).

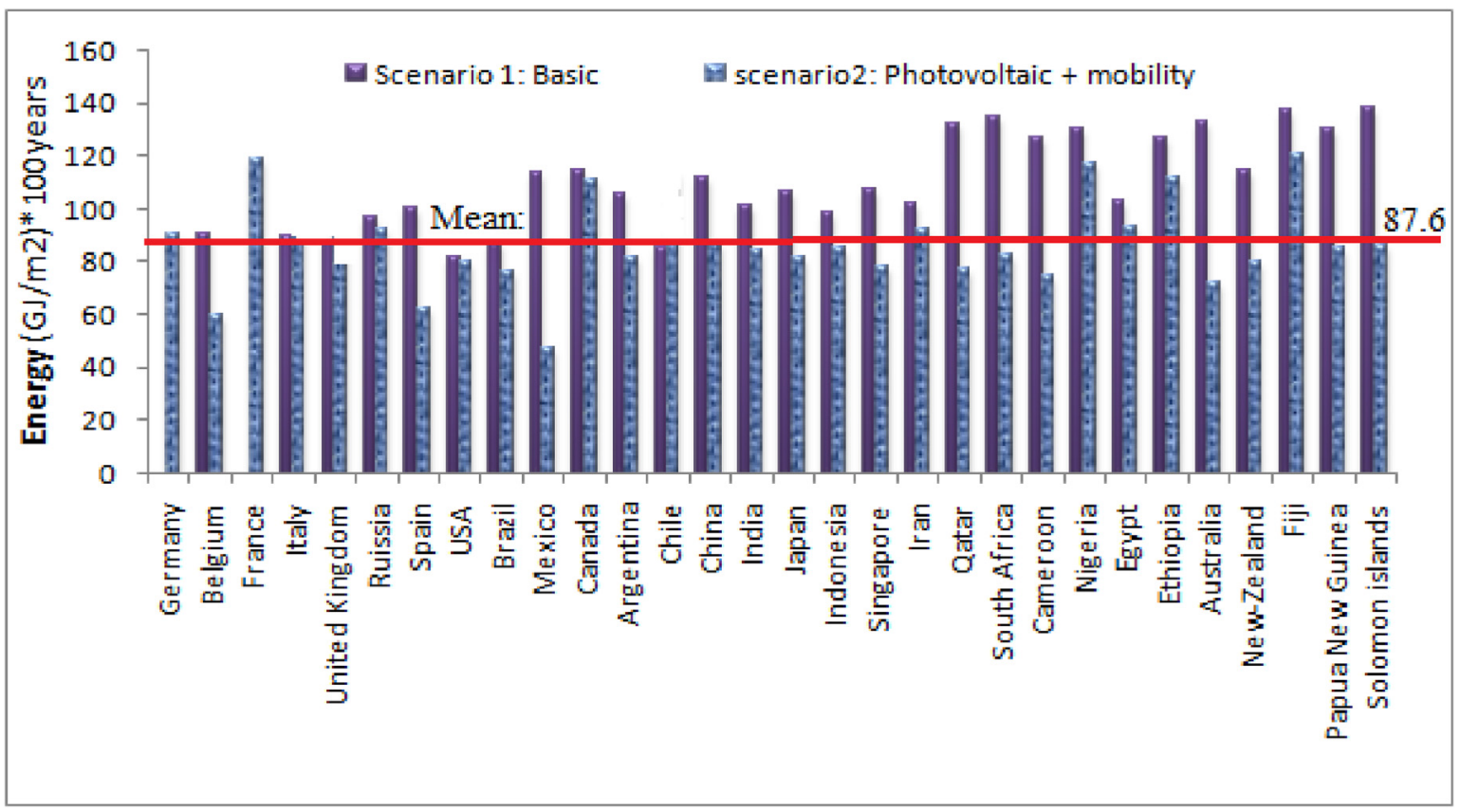

Fig. 7. Comparative Diagram of the Primary Energy Demand of the "Initial" and "Photovoltaic" Scenarios (Functional Unit: Entire neighborhood).

Transportation has also a significant effect on the environmental impact. The studied buildings have high energy performance and thus low heating consumption compared to old buildings, whither heating and cooling energy demand is very high. As shown on Fig. 10, "electricity" is the main component of energy demand (37.5\%)in all the three studied zones(temperate, hot and cold). It is interesting to notice that electricity demand is over $50 \%$ in some countries such as USA, Spain, and Argentina. Only 5.0\% of the total energy demand is associated with transportation in this econeighborhood. Fig. 11 shows the percentage of the different environmental components in the generation of the biodiversity demand, for representative countries located in the seven climate types of the world(polar climate, oceanic, continental, Mediterranean, equatorial, tropical, and arid). Overall, one of the main components having a significant effect on the biodiversity damage is the waste (36.1\%). Only $1.1 \%$ of biodiversity damage comes from "transportation" in the seven climate types distributed in the world.

In a temperate climate, material wastes contribute to $85.3 \%$ of biodiversity damage in Belgium, 78.5\% in the UK, 76.2\% in Germany, and $67.5 \%$ in France. While in tropical and equatorial climates, domestic and material wastes contribute up to $66.7 \%$ of biodiversity damage in Nigeria, 63.4\% in Madagascar, and 68.3\% in Singapore. In the USA, $77.2 \%$ of biodiversity damage is related to the building 


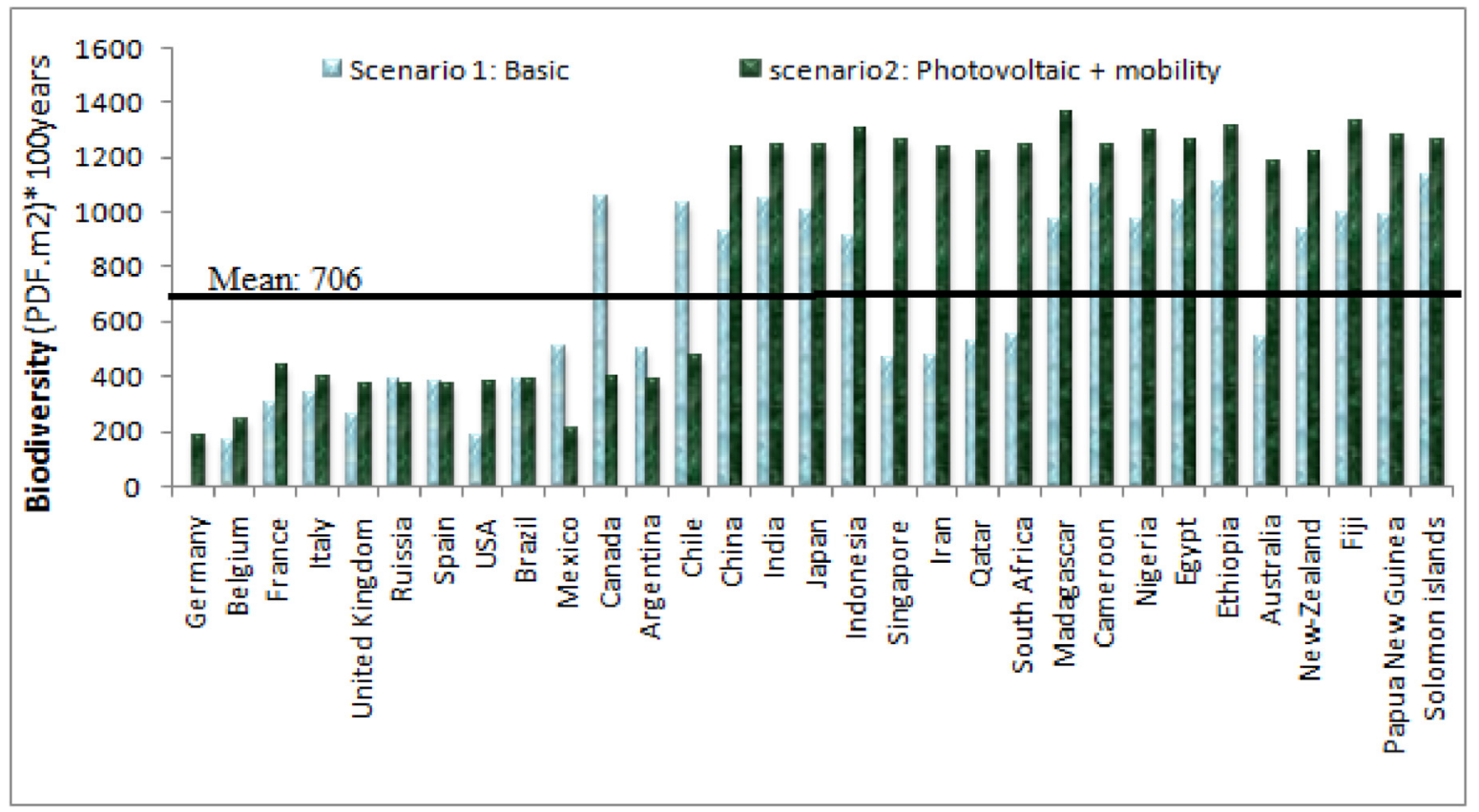

Fig. 8. Comparative Diagram of the biodiversity demand of the "Basic" and "Photovoltaic" Scenarios (Functional Unit: Entire neighborhood).

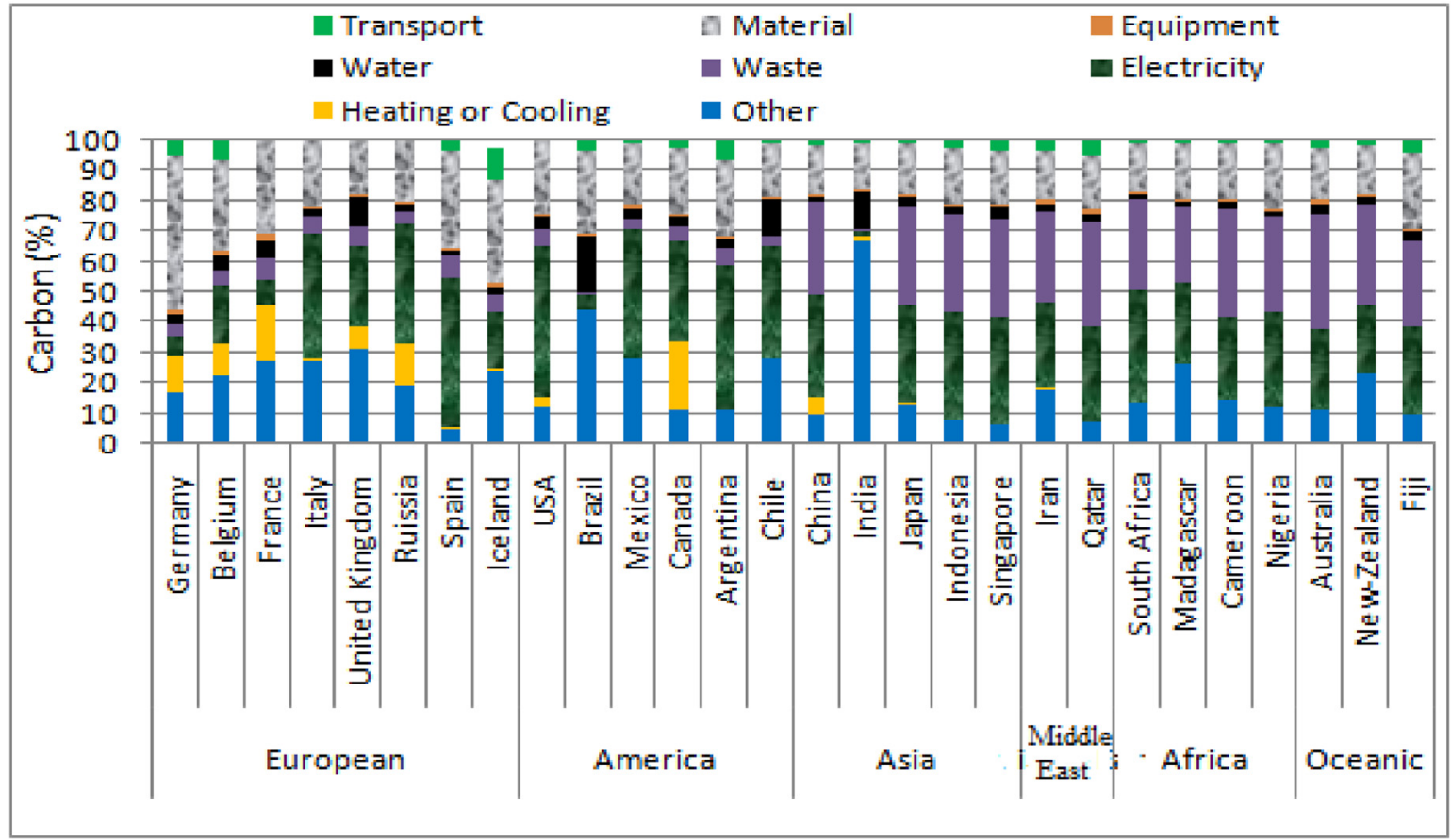

Fig. 9. Frequency (\%) of the different environmental components in the generation of the greenhouse effect, for some countries located in the five continents of the world.

materials and $11.9 \%$ to electricity production. However, in Japan, waste material produces69.4\%, of biodiversity damage.

Fig. 12 shows the deviation of three impacts in some regions of the world. This analysis allows us to understand in depth the rate of environmental impact in each region. Why one region is more impacted than the other. The deviation of energy and carbon impacts is very high in central Europe. Indeed, the results show, at the eco-neighborhood scale, that the carbon emission in Poland is higher than in the central European region. This can be due to the high use rate of fossil fuel energy in their energy mix (more than
83\%, according to IEA [32]). In addition, deviation from biodiversity damage is more significant in southern America. Indeed, it is seen that biodiversity damage is very high in Bolivia, Peru, and Paraguay, but, low, in Brazil and Argentina.

These results show that most of the environmental impacts of buildings come from waste and electricity production. These results are similar to those found by Blengini [53]. 


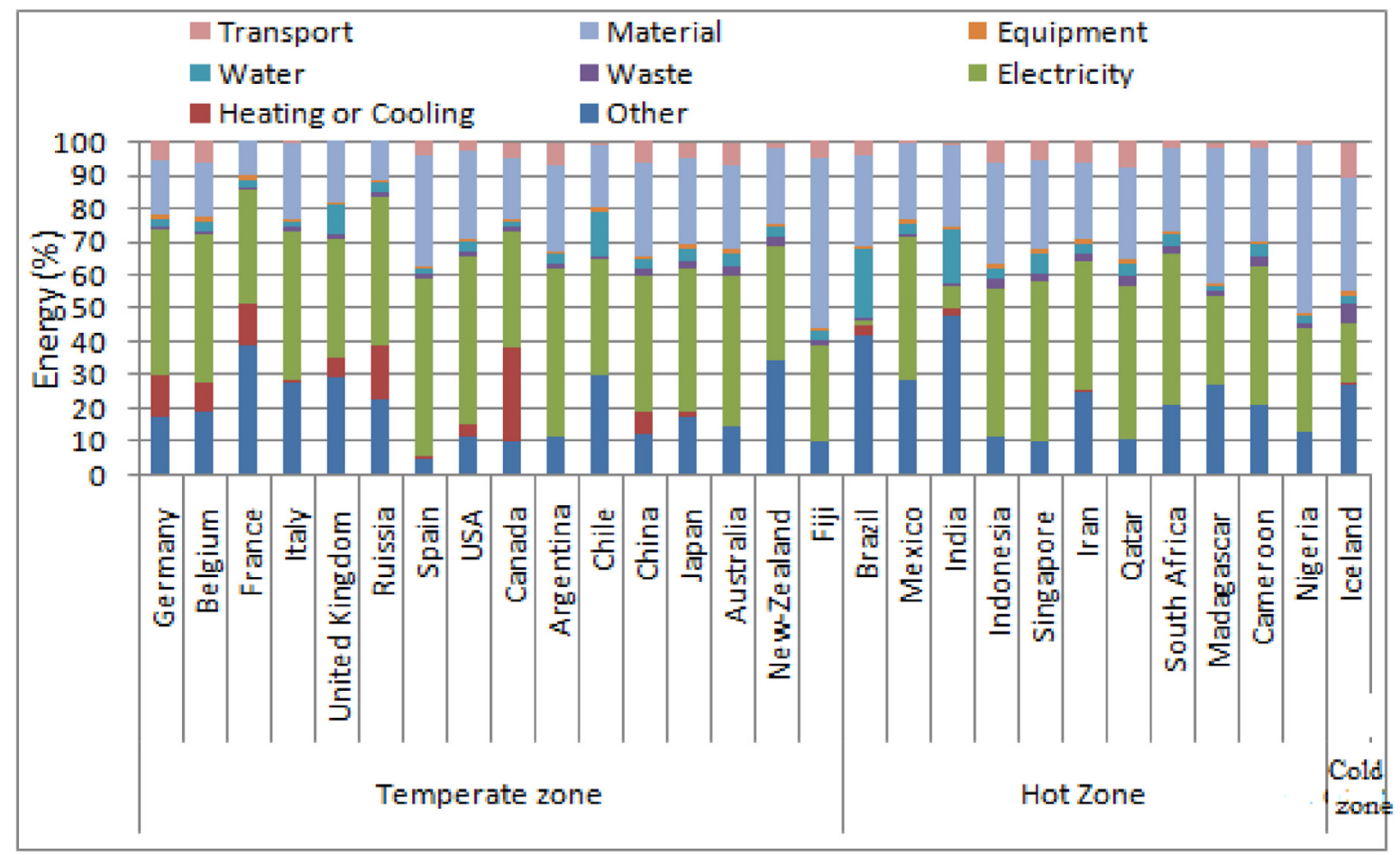

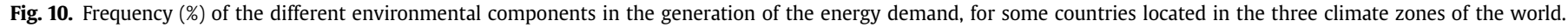

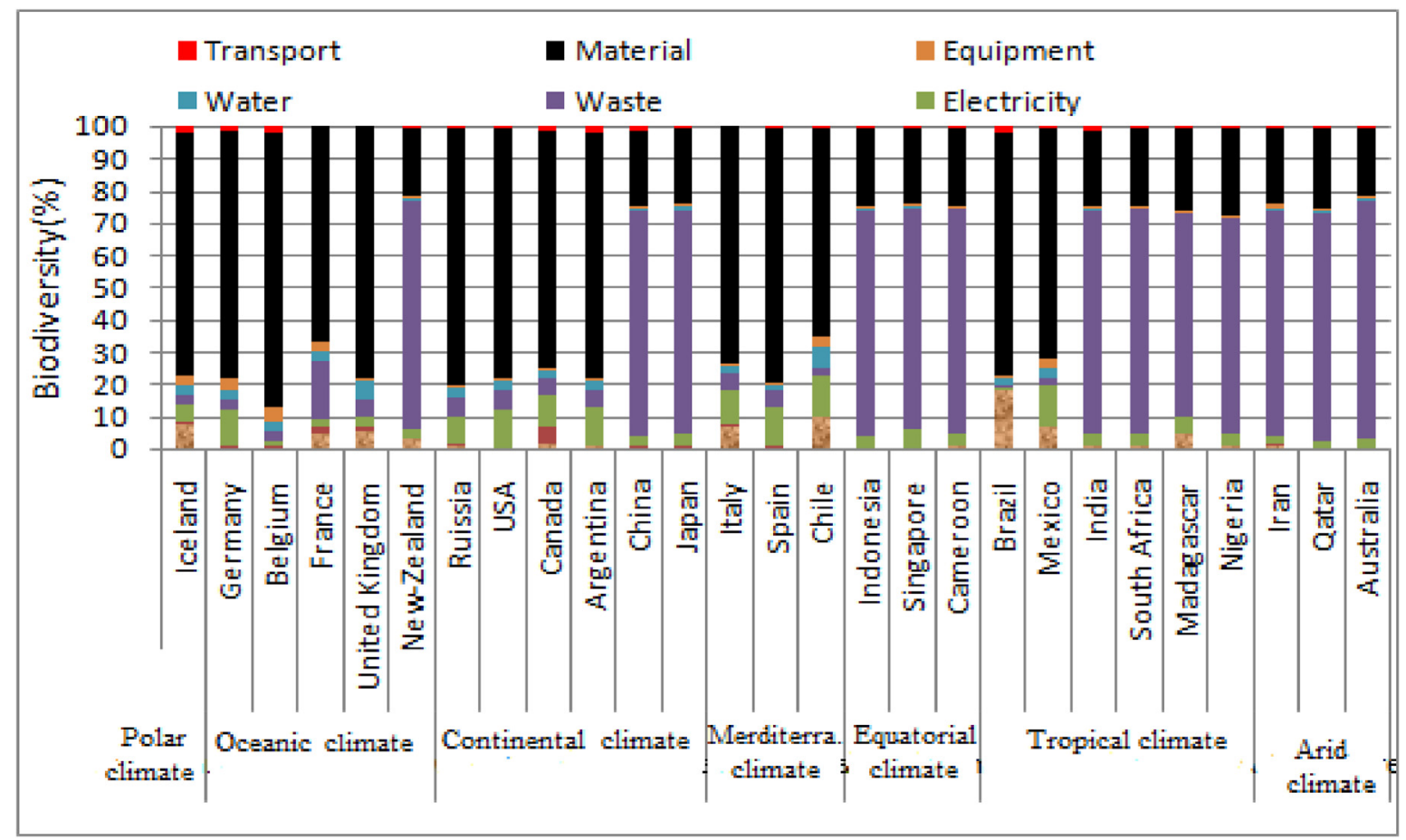

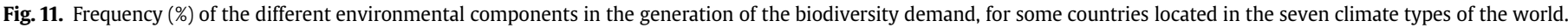

\section{Discussions}

In 2013, the United Nations [54] stated that more than 50\% of the world's population lives in cities. This rate will increase by up to $70 \%$ in the next decade. In addition, the building sector is one of the most consumer-intensive sectors in terms of natural resources, especially fossil fuels. It induces enormous environmental impacts. In developed countries, the construction sector is responsible for $42 \%$ of final energy consumption [55], 35\% of greenhouse gas emissions [56], and $50 \%$ of all-material extractions [57]. This research shows the significant impact of the energy mix on the different environmental impacts. This conclusion confirms the 
Table 7

Environmental cost of each phase of the eco-neighborhood in Belgium.

\begin{tabular}{|c|c|c|c|c|c|}
\hline Environmental impacts & Year & Construction (in $€$ ) & Operation (in $€$ ) & Maintenance (in $€$ ) & Dismantling (in $€$ ) \\
\hline \multirow[t]{4}{*}{ Greenhouse effect } & 2017 & 4166 & 9179 & 409 & 47 \\
\hline & 2020 & 12499 & 27537 & 1227 & 140 \\
\hline & 2030 & 54162 & 119326 & 5316 & 605 \\
\hline & 2050 & 137488 & 302904 & 13494 & 1535 \\
\hline \multirow[t]{4}{*}{ Energy } & 2020 & 215714 & 701031 & 35447 & 3879 \\
\hline & 2030 & 934763 & 3037824 & 153606 & 16807 \\
\hline & 2050 & 2372859 & 7711399 & 389922 & 42663 \\
\hline & 2080 & 4530004 & 14721762 & 744423 & 81448 \\
\hline \multirow[t]{4}{*}{ Biodiversity damage } & 2020 & 28855 & 3481 & 1303 & 26 \\
\hline & 2030 & 125036 & 15084 & 5646 & 114 \\
\hline & 2050 & 317403 & 38291 & 14331 & 289 \\
\hline & 2080 & 605952 & 73100 & 27360 & 553 \\
\hline Total(\%) & - & 24.8 & 71.1 & 3.7 & 0.4 \\
\hline
\end{tabular}

results found by Rossi et al. $[48,49]$ who showed that the energy mix of one country has a significant impact on $\mathrm{CO}_{2}$ emissions. These researchers showed how a shift in the energy mix towards renewable sources yields important reductions, even without reducing energy consumptions.

Our study shows that the carbon emission rate is very high in China, Australia, Mongolia, Madagascar, and South Africa. These results are normal because more than $80 \%$ of the energy consumed in these countries is produced by fossil fuels such as coal, oil, etc. In countries such as Brazil, Costa Rica, Denmark, Sweden, Finland, and the UK, the emission rate is low because of the large-scale implementation of renewable energy in the production of consumed energy. In addition, in Germany, Russia, and the USA, the rate of greenhouse gas emissions is moderately important because heating and electricity are for the most part produced by gas, nuclear, and renewable energies. Most fossil fuel energy in these three countries is used to supply industries.

In Europe, in 2008, only $8.5 \%$ of energy consumption comes from renewable and clean resources [58]. The 2014 climate-energy package sets new targets for 2030: $40 \%$ reduction in greenhouse gas emissions compared to 1990, 27\% renewable energy in the energy mix; and $27 \%$ energy efficiency. More than $27 \%$ of the energy consumed in Denmark and Costa Rica is renewable which explains their low carbon emission on the neighborhood scale.

Overall, the influence of energy mix over the environmental impacts varied in each country: in France, $74 \%$ of nuclear in the energy mix, produces very low CO2; in Germany, and Denmark, much higher renewable energy in the energy mix than most countries produces lower $\mathrm{CO} 2$ than average; in Poland, $90 \%$ of fossil energy in the energy mix produces much higher $\mathrm{CO}$; in China, $64 \%$ of coal accentuates the pollution rate. The implementation of renewable and nuclear energies will radically alter grid emissions in the world. These findings confirm the researches of Sharif et al. [59] who showed that the use of nonrenewable energy has still, positive impacts on environmental damage, while renewable energy has a negative effect on environmental damage and allows to mitigate environmental hazards.

Energy demand is very high in Canada, Australia, and South Africa, but moderate in Brazil, Norway, Cameroon, and Singapore. This confirms some of the results found by Berardi [60].

In Madagascar,70\% of the energy consumed comes from coal. While in Chad, more than $40 \%$ of energy is used for cooling. Overall, in this study, heating energy in countries located in temperate and polar areas and cooling for hot-zone countries is very low compared to those found in other works [48]. This is due to the fact that our study took place exclusively in an eco-neighborhood. Indeed, in this kind of neighborhood, they implement various passive design strategies in the design of their buildings. The mean value for the neighborhood located in 150 countries is $0.25 \mathrm{~kg}$ of $\mathrm{CO}_{2} / \mathrm{kWh}$.

The results show that biodiversity damage is high in Sub-Sahara Africa, and Middle East (more than 8 millionsPDFm ${ }^{2}$.year), but, lower in USA, Brazil, European Union, Russia, and Australia(less than 2 millionsPDFm².year). Globally, the causes of biodiversity degradation are direct and indirect. But, they are largely the result of uncontrolled human expansion and predominance. It should be noted that certain chemical pollutants emitted during the production of nuclear energy and the waste discharged into the environment during the refining of petroleum have a significant effect on the destruction of the environment. These chemical pollutants emitted are also often toxic to human beings.

Following the involvement of humans in the destruction of the environment (industry, deforestation ...), in recent years, biodiversity has become a world heritage of humanity and the majority of people agree that it must be protected and amplified.

Stamatiou and Dritsakis [61] showed that there is a great relationship between $\mathrm{CO}_{2}$ emissions, energy consumption, and economic growth in each country. This finding is confirmed by some results of this research. Indeed, the implementation of a photovoltaic panel on a sustainable neighborhood mitigates $15.9 \%$ ofCO 2 and $21.2 \%$ of energy; but, unfortunately, biodiversity damage increased by $25.0 \%$. According to Nian [62], one of the aims of the solar photovoltaic systems (PV) is mainly to mitigate carbon emissions of energy systems. Globally, PV systems give nearly zero carbon emission when in operation, but the manufacturing phases produce carbon emissions. There was no study to deeply investigate the impacts of PV systems on the biodiversity damages. Carbon emissions from photovoltaic panels and nuclear energy production are low during the operational phase. However, their life cycle is not free of carbon emissions. In fact, the manufacture of PV systems requires a significant amount of materials such as metal, petrochemicals, contributing to the pollution of the environment [63]. Material wastes and electricity are the two main components that affect carbon dioxide emissions and energy consumption in a sustainable neighborhood. The waste shows a more significant effect on biodiversity degradation. It is seen that all fossil fuel energy sources do not increase the negative environmental impacts in the same way. Indeed, the type of fossil energy sources used to produce electricity greatly influences the environmental impact. If we impose a new energy and electricity mix for all the studied countries, including for example $27 \%$ of renewable sources (on the basis of the objectives set in the European Union in 2014, horizon 2030), we observe a direct reduction of greenhouse gas emissions between $15 \%$ and $40 \%$ and reduction of the total primary energy demand of $10 \%-30 \%$. The results showed that, at the sustainable neighborhood scale, the ECC of the greenhouse effect is $35.6 \%$, 
Table 8

Comparison of the three environmental impacts and costs calculated over one year on our reference scenario.

\begin{tabular}{|c|c|c|c|c|c|c|c|c|c|c|c|c|c|}
\hline \multirow[b]{3}{*}{ Continents } & \multirow[b]{3}{*}{ countries } & \multicolumn{4}{|c|}{ Greenhouse effect(kg CO 2 eq/year) } & \multicolumn{4}{|c|}{ Energy demand(kWh/year) } & \multicolumn{4}{|c|}{ Biodiversity demand(PDF.m².year) } \\
\hline & & \multicolumn{2}{|l|}{ Basic } & \multicolumn{2}{|c|}{ Photovoltaic + mobility } & \multicolumn{2}{|l|}{ Basic } & \multicolumn{2}{|c|}{ Photovoltaic + mobility } & \multicolumn{2}{|l|}{ Basic } & \multicolumn{2}{|c|}{ Photovoltaic + mobility } \\
\hline & & LCA & $\mathrm{ECC}($ in $€)$ & LCA & ECC $($ in $€)$ & LCA & ECC (in $€)$ & LCA & ECC (in $€)$ & LCA & ECC (in $€)$ & LCA & ECC $($ in $€$ \\
\hline \multirow[t]{7}{*}{ European } & Germany & 372270 & 18613.5 & 339460 & 16973 & 1656336.1 & 331267.2 & 1526047.2 & 305209.4 & 12117.72 & 7149.44 & 23357.52 & 13780.93 \\
\hline & Belgium & 304630 & 15231.5 & 276010 & 13800.5 & 1660858.3 & 332171.7 & 1593450 & 318690 & 10727.78 & 6329.39 & 22901.29 & 13511.76 \\
\hline & France & 292060 & 14603 & 217900 & 10895 & 2170869.4 & 434173.9 & 1887647.22 & 377529.4 & 20077.9 & 11845.96 & 28719.24 & 16944.35 \\
\hline & Italy & 377920 & 18896 & 371580 & 18579 & 1661236.1 & 332247.2 & 1636533.33 & 327306.7 & 22039.44 & 13003.24 & 26319.12 & 15528.28 \\
\hline & UK & 366920 & 18346 & 325420 & 16271 & 1715161.1 & 343032.2 & 1611238.88 & 322247.7 & 17029.63 & 10047.48 & 24454.19 & 14427.97 \\
\hline & Russia & 425530 & 21276.5 & 370180 & 18509 & 1767333.33 & 353466.7 & 1693230.55 & 338646.1 & 25842.34 & 15246.98 & 24247.85 & 14306.23 \\
\hline & Spain & 426090 & 21304.5 & 260680 & 13034 & 1833138.88 & 366627.8 & 1140038.888 & 228007.8 & 25208.71 & 14873.13 & 24479.08 & 14442.66 \\
\hline \multirow[t]{6}{*}{ America } & USA & 341730 & 17086.5 & 317820 & 15891 & 1490122.22 & 298024.4 & 1464891.66 & 292978.3 & 12180.01 & 7186.21 & 24978.28 & 14737.18 \\
\hline & Brazil & 365600 & 18280 & 316610 & 15830.5 & 1584058.33 & 316811.7 & 1399094.4 & 279818.9 & 25536.64 & 7660.992 & 25534.62 & 7660.4 \\
\hline & Mexico & 493740 & 24687 & 402560 & $20128 €$ & 2076305.55 & 415261.1 & 1708875 & 341775 & 33649.49 & 10094.84 & 26929.1 & 8078.73 \\
\hline & Canada & 518260 & 25913 & 377170 & 18858.5 & 2100008.33 & 420001.7 & 2022911.1 & 404582.2 & 69336.5 & 40908.53 & 25979.64 & 15327.98 \\
\hline & Argentina & 443530 & 22176.5 & 341050 & 17052.5 & 1936288.88 & 387257.8 & 1487450 & 297490 & 32997.4 & 9899.22 & 25430.39 & 7629.11 \\
\hline & Chile & 469130 & 23456.5 & 47500 & 2375 & 2073016.66 & 414603.3 & 1563769.4 & 312753.9 & 67653,89 & 20296.2 & 31395.93 & 9418.78 \\
\hline \multirow[t]{7}{*}{ Asia } & Chine & 510460 & 25523 & 520320 & 26016 & 2051986.11 & 410397.2 & 1598247.22 & 319649.4 & 61030.57 & 18309.15 & 81297.2 & 24389.16 \\
\hline & India & 486390 & 24319.5 & 514100 & 25705 & 1846147.22 & 369229.44 & 1549205.5 & 309841.1 & 68736,05 & 20620.8 & 81938.31 & 24581.5 \\
\hline & Japan & 508230 & 25411.5 & 489280 & 24464 & 1952113.88 & 390422.8 & 1500852.77 & 300170.6 & 65909.55 & 38886.6 & 81935.39 & 48341.9 \\
\hline & Indonesia & 453640 & 22682 & 487640 & 24382 & 1803394.44 & 360678.9 & 1489833.3 & 297966.7 & 60147.57 & 18044.25 & 81865.95 & 24559.78 \\
\hline & Singapore & 415650 & 20782.5 & 480810 & 24040.5 & 1960866.66 & 392173.3 & 1435263.8 & 287052.8 & 30644.21 & 9193.26 & 83284.33 & 24985.3 \\
\hline & Iran & 376210 & 18810.5 & 514840 & 25742 & 1863983.3 & 372796.7 & 1681958.3 & 336391.7 & 31270.97 & 9381.3 & 81524.25 & 24457.3 \\
\hline & Qatar & 561770 & 28088.5 & 457340 & 22867 & 2409533.3 & 481906.7 & 1415516.66 & 283103.33 & 34654,65 & 20446.24 & 80186.82 & 47310.22 \\
\hline \multirow{6}{*}{ Africa } & South Africa & 624970 & 31248.5 & 527400 & 26370 & 2467238.8 & 493447.8 & 1508552.7 & 301710.5 & 36080.17 & 10824.054 & 81642.23 & 24492.6 \\
\hline & Madagascar & 620460 & 31023 & 622800 & 31140 & 2272436.1 & 454487.22 & 2414002.77 & 482800.6 & 63973.27 & 19191.96 & 89621.8 & 26886.54 \\
\hline & Cameroon & 643200 & 32160 & 447990 & 22399.5 & 2319786.1 & 463957.22 & 1366175 & 273235 & 72245.24 & 21673.57 & 81922.94 & 24576.88 \\
\hline & Nigeria & 638970 & 31948.5 & 498630 & 24931.5 & 2379411.1 & 475882.2 & 2145458.33 & 429091.6 & 63988,74 & 19196.61 & 85300.61 & 25590.18 \\
\hline & Egypt & 552810 & 27640.5 & 522110 & 26105.5 & 1885786.11 & 377157.2 & 1704691.6 & 340938.3 & 68556.67 & 20566.98 & 83115.62 & 24934.68 \\
\hline & Ethiopia & 638570 & 31928.5 & 507580 & 25379 & 2313519.4 & 462703.9 & 2043580.55 & 408716.1 & 72669.34 & 21800.79 & 86144.3 & 25843.3 \\
\hline \multirow[t]{4}{*}{ Oceanic } & Australia & 550670 & 27533.5 & 410720 & 20536 & 2433569.4 & 486713.8 & 1322666.6 & 264533.3 & 35614.14 & 21012.34 & 77836.22 & 45923.36 \\
\hline & New Zealand & 565520 & 28276 & 459580 & 22979 & 2087488.8 & 417497.8 & 1465583.3 & 293116.7 & 61865.27 & 18559.58 & 79969.88 & 23990.96 \\
\hline & Fiji & 668040 & 33402 & 543710 & 27185.5 & 2465169.4 & 493033.9 & 2209038.8 & 441807.8 & 65470.38 & 19641.11 & 87710.42 & 26313.12 \\
\hline & Solomonislands & 692410 & 34620.5 & 456990 & 22849.5 & 2533758.3 & 506751.7 & 1580527.77 & 316105.5 & 74453.59 & 22336.1 & 82914.82 & 24874.44 \\
\hline
\end{tabular}


Table 9

Cost and environmental impacts in some regions in the world.

\begin{tabular}{|c|c|c|c|c|c|c|c|c|c|}
\hline \multirow[t]{4}{*}{ Region } & \multirow{4}{*}{$\begin{array}{l}\text { Contribution } \\
\frac{\text { usedcountries }}{\text { totalcountries }}\end{array}$} & \multicolumn{3}{|c|}{ Greenhouse effect ( $\mathrm{tCO}_{2} \mathrm{eq} /$ year) } & \multicolumn{2}{|c|}{$\begin{array}{l}\text { Energy demand (GJ/ } \\
\text { year) }\end{array}$} & \multicolumn{3}{|c|}{ Biodiversity demand } \\
\hline & & \multirow{3}{*}{$\begin{array}{l}\text { Mean } \\
\text { LCA }\end{array}$} & Mean & \multirow[t]{3}{*}{ Total } & \multirow[t]{2}{*}{ Mean } & \multirow[t]{3}{*}{ Total } & \multirow{3}{*}{$\frac{\text { Mean }}{\text { LCA }}$} & \multirow{3}{*}{$\frac{\text { Mean }}{\operatorname{ECC}(\text { in } €)}$} & \multirow[t]{3}{*}{ Total } \\
\hline & & & ECC & & & & & & \\
\hline & & & $($ in $€)$ & & LCA & & & & \\
\hline $\begin{array}{l}\text { Northern } \\
\text { Africa }\end{array}$ & $6 / 7$ & 544.44 & 27222 & 3266.6 & 6718.3 & 40309.8 & 82346.6 & 48584.5 & 494079.8 \\
\hline $\begin{array}{l}\text { Northern } \\
\text { European }\end{array}$ & $7 / 10$ & 282.96 & 14148 & 1980.77 & 6135.9 & 42951.2 & 25151.9 & 14839.6 & 176062.1 \\
\hline $\begin{array}{l}\text { Northern } \\
\text { America }\end{array}$ & $12 / 24$ & 448.1 & 22405 & 4928.87 & 7073.1 & 77803.3 & 59198.8 & 34927.3 & 640187.5 \\
\hline $\begin{array}{l}\text { Northern } \\
\text { Asia }\end{array}$ & $1 / 4$ & 636.9 & 31845 & 636.9 & 8267.4 & 8267.4 & 85127.5 & 50225.2 & 85127.5 \\
\hline $\begin{array}{l}\text { Southern } \\
\text { Africa }\end{array}$ & $11 / 13$ & 510.7 & 25535 & 5617.4 & 6709.9 & 73809.1 & 78929.8 & 46568.6 & 868228.4 \\
\hline $\begin{array}{l}\text { Southern } \\
\text { European }\end{array}$ & $9 / 18$ & 347.2 & 17360 & 3124.3 & 5570.0 & 50130 & 31811.4 & 18769 & 286302.9 \\
\hline $\begin{array}{l}\text { Southern } \\
\text { America }\end{array}$ & $9 / 12$ & 368.8 & 18440 & 3319.5 & 6108.2 & 54973.9 & 44344.1 & 26163 & 399096.6 \\
\hline $\begin{array}{l}\text { Southern } \\
\text { Asia }\end{array}$ & $13 / 19$ & 484.6 & 24230 & 6429.3 & 5929.3 & 77080.9 & 82101.6 & 48439.9 & 1067321.2 \\
\hline $\begin{array}{l}\text { Central } \\
\text { Africa }\end{array}$ & $7 / 8$ & 508.5 & 25425 & 3559.8 & 6977.5 & 48842.6 & 84518.2 & 49865.7 & 591627.4 \\
\hline $\begin{array}{l}\text { Central } \\
\text { European }\end{array}$ & $6 / 9$ & 458.7 & 22935 & 2752.5 & 7536.3 & 45217.6 & 27206.2 & 16051.7 & 163236.8 \\
\hline $\begin{array}{l}\text { Central } \\
\text { America }\end{array}$ & $4 / 7$ & 435.9 & 21765 & 1743.6 & 7267.9 & 29071.5 & 67841.9 & 40026.72 & 271367.6 \\
\hline $\begin{array}{l}\text { Central } \\
\text { Asia }\end{array}$ & $1 / 5$ & 636.9 & 31845 & 636.9 & 8267.4 & 8267.4 & 85127.5 & 50225.2 & 85127.5 \\
\hline $\begin{array}{l}\text { West } \\
\text { Africa }\end{array}$ & $15 / 16$ & 509.1 & 25455 & 7636.7 & 6761.6 & 101424.9 & 82282.8 & 48547 & 1234241.6 \\
\hline $\begin{array}{l}\text { West } \\
\text { European }\end{array}$ & $6 / 7$ & 374.6 & 18730 & 2247.9 & 6647.1 & 39882.9 & 26238.6 & 15480.8 & 157431.9 \\
\hline $\begin{array}{l}\text { West } \\
\text { Asia }\end{array}$ & $12 / 14$ & 516.9 & 25845 & 6203.1 & 5786.6 & 69439.9 & 74743.6 & 44099 & 896923.6 \\
\hline East Africa & $10 / 11$ & 527.9 & 26395 & 5279.5 & 7281.6 & 72815.8 & 833776.8 & 49193 & 833776.8 \\
\hline East European & $6 / 10$ & 554 & 27700 & 3032.2 & 7867.2 & 47203.4 & 27079.8 & 15977 & 162478.9 \\
\hline East Asia & $4 / 6$ & 500.2 & 25010 & 2000.6 & 5694.8 & 22779.4 & 81775.1 & 48247 & 327100.5 \\
\hline $\begin{array}{l}\text { European } \\
\text { Union }\end{array}$ & $22 / 28$ & 384.8 & 19240 & 8465.8 & 6556.3 & 144238.8 & 26550.1 & 15664.6 & 584102.9 \\
\hline Africa union & $49 / 51$ & 520.2 & 26010 & - & 6889.8 & - & - & - & - \\
\hline Middle East & $14 / 16$ & 508.3 & 25415 & 7116.3 & 5781.9 & 80947.1 & 72071.8 & 42522.4 & 1009005.9 \\
\hline Caribbean America & $4 / 15$ & 521.93 & 26096.5 & 2087.7 & 7505.9 & 30023.7 & 72733.2 & 42912.6 & 290932.9 \\
\hline
\end{tabular}

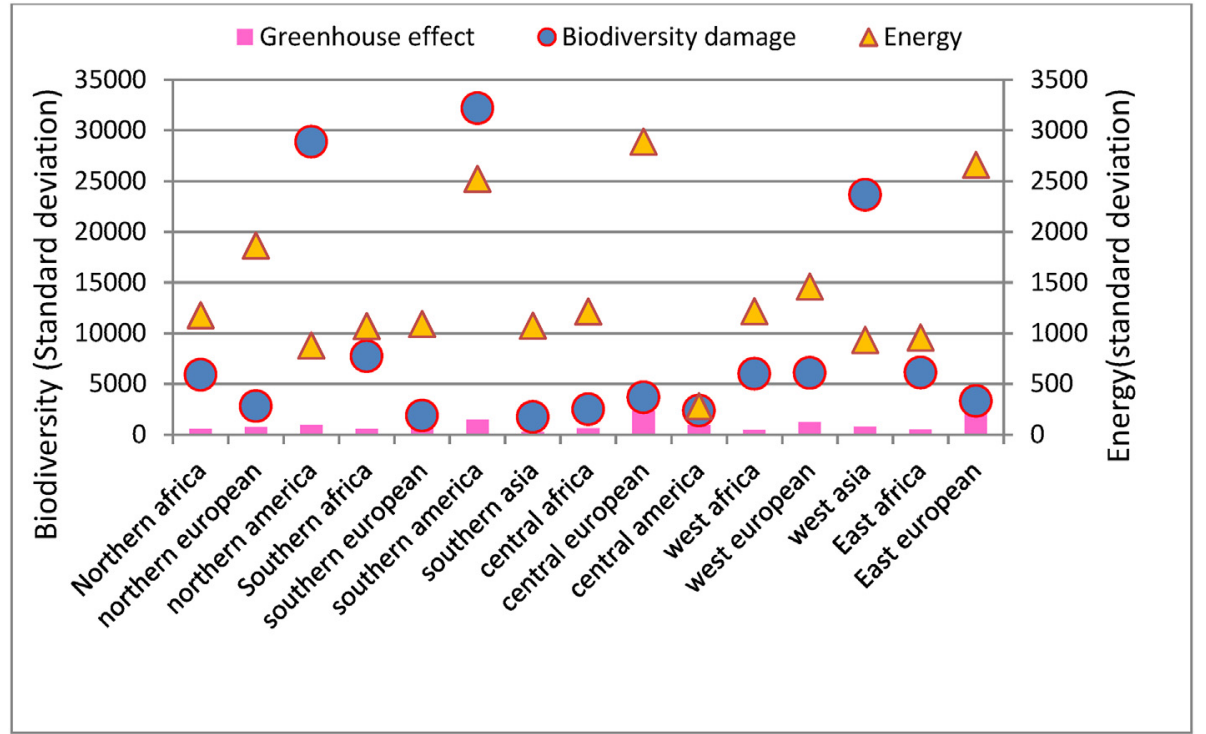

Fig. 12. Standard deviation of the three environmental impacts of an eco-neighborhood in some regions of the world. 
35.2\%, and 32.1\%higher in Africa, Caribbean America, and the MiddleEast, respectively than in European Union.

The vulgarization and implementation of eco-neighborhoods in the world can constitute one of the first solutions to preserve our environment. The results of this study show a reduction in heating energy consumption of $85 \%$, and a reduction of the total ecological footprint of $90 \%$ compared to a standard neighborhood in Belgium, built in a more conventional way [64]. The application of renewable energy (wind turbine, photovoltaic panel, etc.), reduces the greenhouse effect concentration and energy demand in the scale of the neighborhood [67,68].

\section{Conclusions}

This research focuses on the life cycle assessment and evaluation of the environmental costs of an eco-neighborhood initially located in Belgium. The same neighborhood is built in 149 other countries by respecting some parameters own at each country, such as the use of different materials, the heating/cooling systems, the energy mix, the buildings' insulation thicknesses, mobility, the climate-related to the temperatures. Three environmental impacts were quantified in this new neighborhood and then transformed into environmental costs. The energy mix has a significant effect on the different environmental impacts. In some countries such as France, USA, Russia, Belgium, nuclear electricity moderates $\mathrm{CO}_{2}$ emission. In Denmark and Costa Rica where the use of renewable energy is high, $\mathrm{CO}_{2}$ emission is low. Installing photovoltaic panels in an eco-neighborhood mitigates $\mathrm{CO}_{2}$ emission between $16.0 \%$ and 21.2\%. The influence of PV on energy demand and biodiversity degradation is the most significant in the hot climate.15.5\% of total energy cost can be saved. In a sustainable neighborhood, the transportation sector generates low environmental impacts compared to the waste, which is one of the most important sources of environmental impacts on this scale. The research methodology used in this paper is reproducible to other regions and countries, even under different climates. In the future, our work will focus on the analysis of the environmental cost and optimization of a more standard neighborhood, built in a more conventional way as well as on research studying the impacts of climates and energy mix on the environmental costs of old neighborhoods.

\section{Declaration of competing interest}

The authors declare that they have no known competing financial interests or personal relationships that could have appeared to influence the work reported in this paper.

\section{References}

[1] IPCC, Summary for policy makers, in: Climate: The Physical Science Basis, Contribution of Working Group I to the Fifth Assessment Report of the Intergovernmental Panel on Climate Change, 2013.

[2] IPCC, Climate Change 2007: Synthesis Report. Contribution of Working Groups I, II, and III to the Fourth Assessment Report of the Intergovernmental Panel on Climate Change, Cambridge University Press, Cambridge, UK, 2007.

[3] International Energy AgencyTransition to Sustainable Buildings, Strategies and Opportunities to 2050ISBN: 978-92-64-20241-20242, 2013.

[4] I. Artola, K. Rademaekers, R. Williams, J. YearwoodBoosting building renovation: what potential and value for Europe?PE 587 (2016) 326.

[5] P. Huovila, M. Alla-Juusela, L. Melchert, S. Pouffary, Buildings and Climate Change: Summary for Decision-Makers, United Nations Environment Programme, 2007, pp. 2-56.

[6] KlasEkelöw VlatkoMilić, Bahram Moshfegh, On the performance of LCC optimization software OPERA-MILP by comparison with building energy simulation software IDA ICE, Build. Environ. 128 (2018) 305-319.

[7] Modeste Kameni Nematchoua, José Orosa, Sigrid Reiter, Energy consumption assessment due to the mobility of inhabitants, and multiannual prospective on the horizon 2030-2050; A case of Belgium, Energy 171 (2019) 523-534.

[8] Andrea Invidiata, EnedirGhisi, Impact of climate change on heating and cooling energy demand in houses in Brazil, Energy Build. 130 (2016) 20-32.
[9] Modeste Kameni Nematchoua, Andrianaharison Yvon, Omer Kalameu, Somayeh Asadi, Sigrid Reiter, Impact of climate change on demands for heating and cooling energy in hospitals. An in-depth case study of six islands located in the Indian Ocean region, Sustain. Cities Soc. 44 (2019) 629-645.

[10] Charles-Hubert Born, Valérie Dupont, Charles Poncelet, La compensation écologique desdommages causés à la biodiversité : un mal nécessaire?, in: Aménagement, environnement,urbanisme et droit foncier : revue d'études juridiques, 2012, pp. 12-40. Vol. Numérospécial, no. 3.

[11] M. Buyle, J. Braet, A. Audenaert, Life cycle assessment in the construction sector : a review, Renew. Sustain. Energy Rev. 26 (2013) 379-388, https:// doi.org/10.1016/j.rser.2013.05.011.

[12] K. Simonen, Life Cycle assessment.Pocket Architecture : Technical Design Series, Routledge, London and New York, 2014.

[13] Lotteau, M., Loubet, P., Pousse, M., Dufrasnes, E., \&Sonnemann, G. Critica review of life cycle assessment (LCA) for the built environment at the neighborhood scale. Build. Environ., 93, 165-178. https://doi.org/10.1016/j. buildenv.2015.06.029.

[14] M. Colombert, C. De Chastenet, Y. Diab, C. Gobin, G. Herfray, T. Jarrin, M. Trocmé, Analyse de cycle de vie à l'échelle du quartier: un outil d'aide à la décision? Le cas de la ZAC Claude Bernard à Paris (France), Environ. Urbain UrbanEnviron. 5 (2011) c1-c21.

[15] J. Oliver-Solà, A. Josa, A.P. Arena, X. Gabarrell, J. Rieradevall, The GWP-Chart: an environmental tool for guiding urban planning processes. Application to concrete sidewalks, Cities 28 (2011) 245-250.

[16] M. Lotteau, G. Yepez-Salmon, N. Salmon, Environmental assessment of sustainable neighborhood projects through NEST, a decision support tool for early stage urban planning, Procedia Eng. 115 (2015b) 69-76, https://doi.org/ 10.1016/j.proeng.2015.07.356.

[17] E. Popovici, Contribution à l'analyse de cycle de vie des quartiers( $\mathrm{PhD}$ dissertation), Ecole Nationale supérieure des Mines de Paris, Paris, 2006.

[18] A. Stephan, R.H. Crawford, K. de Myttenaere, Multi-scale life cycle energy analysis of a low-density suburban neighbourhood in Melbourne, Australia, Build. Environ. 68 (2013) 35-49.

[19] J. Norman, H.L. Maclean, M. Asce, C.A. Kennedy, Comparing high and low residential density : life-cycle analysis of energy use and greenhouse gas emissions, J. Urban Plann. Dev. (2006) 10-21.

[20] D. Trigaux, K. Allacker, F. De Troyer, Model for the Environmental Impact Assessment of Neighbourhoods, 2014.

[21] K. Allacker, S. Danielle Maia, S. Serenella, Land use impact assessment in the construction sector: an analysis of LCIA models and case study application, Int J. Life Cycle Assess 19 (2014) 1799-1809, https://doi.org/10.1007/s11367014-0781-7.

[22] L. De Nocker, S. Broekx, I. Liekens, Economischewaardering Van Verbetering Ecologischetoestandoppervlaktewater Op Basis Van Onderzoeksresultatenuit Aquamoney, Vito Intern Rapport 2011/RMA/R/248, 2011, p. 58, 2011.

[23] RistoKosonen TuomoNiemelä, JuhaJokisalo, Energy performance and environmental impact analysis of cost-optimal renovation solutions of large panel apartment buildings in Finland, Sustain. Cities Soc. 32 (2017) 9-30.

[24] A. Atmaca, N. Atmaca, Life cycle energy (LCEA) and carbon dioxideemissions $\left(\mathrm{LCCO}_{2} \mathrm{~A}\right)$ assessment of two residential buildings in Gaziantep,Turkey, Energy Build. 102 (2015) 417-431.

[25] L. Liu, P. Rohdin, B. Moshfegh, LCC assessments and environmental impacts on the energy renovation of a multi-family building from the 1890s, Energy Build. 133 (2016) 823-833.

[26] T. Broström, P. Eriksson, L. Liu, P. Rohdin, F. Ståhl, B. Moshfegh, A method to assess the potential for and consequences of energy retrofits in Swedish historic buildings, Hist. Environ. Pol. Pract. 5 (2014) 150-166.

[27] M.S. Tokarik, R.C. Richman, Life cycle cost optimization of passive energy efficiency improvements in a Toronto house, Energy Build. 118 (2016) 160-169.

[28] S.-I. Gustafsson, Optimal fenestration retrofits by use of MILP programming technique, Energy Build. 33 (2001) 843-851.

[29] MatthewS. Tokarik, RussellC. Richman, Life cycle cost optimization of passive energy efficiency improvements in a Toronto house, Energy Build. 118 (2016) $160-169$.

[30] J. Teller, A.F. Marique, V. Loiseau, F. Godard, C. Delbar, Référentiel Quartiers Durables (Guides Méthodologiques), Namur, Belgique, SPW, DGO4, 2014.

[31] M.G. Riera Perez, E. Rey, A multi-criteria approach to compare urban renewal scenarios for an existing neighborhood. Case study in Lausanne (Switzerland) Build. Environ. 65 (2013) 58-70.

[32] Site web of international energy statistics. https://www.eia.gov/beta/ international/data/browser/\#/?pa $=00000000$ $10000000000000000000000000000000000000000000000000 u \& a m p$; $c=$ ruvvvvvfvtvnvv1 urvvvvfvvvvvvfvvvou20evvvvvvvvvnvvuvo\&amp; $\mathrm{ct}=0 \& a m p ; \mathrm{vs}=\mathrm{INTL} .44-2-\mathrm{BLR}-\mathrm{QBTU} . A \& a m p ; o r d=C R \& a m p ; \mathrm{vo}=0 \& a m p$ $\mathrm{V}=\mathrm{H} \&$ amp; $\mathrm{end}=2016$

[33] Jan Remund, Stefan Müller, Stefan Kunz, Barbara Huguenin-Landl, Christian Studer, René Cattin, Global meteorological database version 7 software and data for engineers, planers and Education.METEOTESTFabrikstrasse $14 \mathrm{CH}-3012$ bern Switzerland. www.meteotest.com, 2017. www.meteonorm. com, 1-17.

[34] B. Peuportier, E. Popovici, M. Troccmé, Analyse du cycle de vie à l'échelle du quartier, bilan et perspectives du projet ADEQU, Build. Environ. 17 (2006) 03(15).

[35] Ecoinvent LCI database. https://simapro.com/databases/ecoinvent/? gclid=CjwKCA jwsdfZBRAkEiwAh2z65sg-fOlOpNksILo.Web site consultedin 
2017

[36] M. Goedkoop, R. Spriensma, The Eco Indicator 99: A Damage Oriented Method for Life Cycle Impact Assessment, 2000, p. p142.

[37] J.B. Guinée, M. Gorréeb, R. Heijungs, G. Huppes, Lyfe Cycle Assessment;an Operational Guide to the ISI Standard, 2001, p. P704.

[38] A. Ellis Byron, Life Cycle Cost, 2007, pp. 2-8. See Barringer's free LCC Excel file at, http://www.barringer1.com/lcc.xls.

[39] T. Salomon, R. Mikolasek, B. Peuportier, Outil de simulation thermique du bâtiment, COMFIE ,fromJournée SFT-IBPSA, Outils de simulation thermoaéraulique du bâtiment, La Rochelle, 2005, p. 8.

[40] Leo De Nocker, V.I.T.O. VITO - WimDebacker, Annex: Monetisation of the MMG Method (Update 2017), 2018, pp. 1-65.

[41] D. Trigauxa, K. Allackera, F. De Troyera, Life cycle assessment of land use in neighborhoods, Procedia Environ. Sci. 38 (2017) 595-602.

[42] United Nations development Programme (UNDP), Fighting Climate Change: Human Solidarity in a Changing World (New York: Human Development Report, UNDP, 2007/2008, p. 87.

[43] L. Gustavsson, A. Joelsson, Life cycle primary energy analysis of residential buildings, Energy Build. 42 (2010) 210-220.

[44] P.J. Burke, Income, resources and electricity mix, Eng. Econ. 32 (2010) 616-626.

[45] P. Hennicke, Scenarios for a robust policy mix: the final report of the German study commission on sustainable energy supply, Energy Pol. 32 (2004) 1673-1678.

[46] P.J. Luickx, L.M. Helsen, W.D. D'haeseleer, Influence of massive heat-pump introduction on the electricity-generation mix and the GHG effect: comparison between Belgium, France, Germany and The Netherlands, Renew. Sustain. Energy Rev. 12 (2008) 2140-2158.

[47] G. Marrero, Greenhouse gases emissions, growth and the energy mix in Europe, Energy Econ. 32 (2010) 1356-1363.

[48] Barbara Rossi, Anne-Françoise Marique, Sigrid Reiter, Life-cycle assessment of residential buildings in three different European locations.basic tool, Build. Environ. 51 (2012) 395-401.

[49] Barbara Rossi, Anne-Francoise Marique, Sigrid Reiter, Life-cycle assessment of residential buildings in three different European locations, case study, Build. Environ. 51 (2012) 402-407.

[50] Ruben Laleman, Johan Albrecht, Dewulf Jo, Life Cycle Analysis to estimate the environmental impact of residential photovoltaic systems in regions with a low solar irradiation, Renew. Sustain. Energy Rev. 15 (2011) 267-281.

[51] N. Jungbluth, M. Tuchschmid, 'Ecoinvent Report N86'. Part XII Photovoltaics, 2007.

[52] Nan Zhou, Nina Khanna, Wei Feng, Ke Jing, Mark Levine, Scenarios of energy efficiency and $\mathrm{CO} 2$ emissions reduction potential in the buildings sector in China to year 2050, Nat. Energy 3 (2018) 978-984. www.nature.com/ natureenergy.

[53] G.A. Blengini, Life cycle of buildings, demolition and recycling potential: a case study in Turin, Italy, Build. Environ. 44 (2009) 319-330.

[54] Nations Unies, Population, Development and the Environment, 2013.

[55] International Energy Agency, World Energy Outlook 2011, 2011.

[56] B. Metz, O. Davidson, P. Bosch, R. Dave, L. Meyer, Contribution of Working Group III to the Fourth Assessment Report of the Intergovernmental Panel on Climate Change, 2007.

[57] Comité européen de normalisation, EN 15978. Contribution des ouvrages de construction au développement durable - Évaluation de la performance environnementale des bâtiments - Méthode de calcul, 2011 (Bruxelles, Belgique).

[58] Agnès Sinaï, Un Paquet Climat-Énergie Européen Sans Audace, 2014. http:// www.journaldelenvironnement.net/article/bruxelles-presente-son-paquetenergie-climat-2030,42055.

[59] Arshian Sharif, Syed Ali Raza, Ilhan Ozturk, Sahar Afshan, The dynamic relationship of renewable and nonrenewable energy consumption with carbon emission: a global study with the application of heterogeneous panel estimations, Renew. Energy 133 (2019) 685-691.

[60] Umberto Berardi, Building energy consumption in US, EU, and BRIC countries, Procedia Eng. 118 (2015) 128-136.

[61] Pavlos Stamatiou, Nikolaos Dritsakis, Dynamic modeling of causal relationship between energy consumption, $\mathrm{CO}_{2}$ emissions, and economic growth in Italy, in: Proceedings in Business and Economics, Springer, 2017, pp. 99-109, https://doi.org/10.1007/978-3-319-48454-9_8Chapter8.

[62] Modeste Kameni Nematchoua, Gh R. Roshan, Rene Tchinda, T. Nasrabadi, Paola Ricciardi, Climate change and its role in forecasting energy demand in buildings: a case study of Douala City, Cameroon, J. Earth Syst. Sci. 124 (2015) 269-281.

[63] V.M. Fthenakis, R. Frischknecht, M. Raugei, H. Kim, E. Alsema, M. Held, et al., Methodology Guidelines on Life Cycle Assessment of Photovoltaic Electricity, second ed., IEA PVPS Task 12: International Energy Agency Photovoltaic PowerSystems Program, 2011.

[64] Marique Anne-Francoise, Reiter Sigrid, A simplified framework to assess the feasibility of zero-energy at the neighbourhood/community scale, Energy Build. 82 (2014) 114-122.

[65] UN-Habitat, Available : https://unhabitat.org/knowledge/research-andpublications, 2019. (Accessed 15 March 2019).

[66] Pleaides LCA, Aaillable : https://www.izuba.fr/logiciels/outils-logiciels/ pleiades-acv/, 2019. (Accessed 15 March 2019) https://unhabitat.org/ knowledge/research-and-publications.

[67] Modeste Kameni Nematchoua, Jose A. Orosa, Cinzia Buratti, Esther Obonyo, Donghyun Rim, Paola Ricciardi, Sigrid Reiter, Comparative analysis of bioclimatic zones, energy consumption, $\mathrm{CO} 2$ emission and life cycle cost of residential and commercial buildings located in a tropical region: a case study of the big island of Madagascar, Energy 202 (2020) 117754.

[68] Modeste Kameni Nematchoua, Paola Ricciardi, José A. Orosa, Cinzia Buratti, A detailed study of climate change and some vulnerabilities in Indian Ocean: A case of Madagascar island, Sustain. Cities Soc. 41 (2018) 886-898. 